\title{
Caustic-Side Solvent Extraction Solvent-Composition Recommendation
}
L. N. Klatt
J. F. Birdwell, Jr.
P. V. Bonnesen
L. H. Delmau
L. J. Foote
D. D. Lee
R. A. Leonard
T. G. Levitskaia
M. P. Maskarinec
B. A. Moyer 


\title{
DOCUMENT AVAILABILITY
}

Reports produced after January 1, 1996, are generally available free via the U.S. Department of Energy (DOE) Information Bridge:

Web site: http://www.osti.gov/bridge

Reports produced before January 1,1996, may be purchased by members of the public from the following source:

\author{
National Technical Information Service \\ 5285 Port Royal Road \\ Springfield, VA 22161 \\ Telephone: 703-605-6000 (1-800-553-6847) \\ TDD: 703-487-4639 \\ Fax: 703-605-6900 \\ E-mail: info@ntis.fedworld.gov \\ Web site: http://www.ntis.gov/support/ordernowabout.htm
}

Reports are available to DOE employees, DOE contractors, Energy Technology Data Exchange (ETDE) representatives, and International Nuclear Information System (INIS) representatives from the following source:

Office of Scientific and Technical Information

P.O. Box 62

Oak Ridge, TN 37831

Telephone: 865-576-8401

Fax: 865-576-5728

E-mail: reports@adonis.osti.gov

Web site: http://www.osti.gov/contact.html

This report was prepared as an account of work sponsored by an agency of the United States Government. Neither the United States government nor any agency thereof, nor any of their employees, makes any warranty, express or implied, or assumes any legal liability or responsibility for the accuracy, completeness, or usefulness of any information, apparatus, product, or process disclosed, or represents that its use would not infringe privately owned rights. Reference herein to any specific commercial product, process, or service by trade name, trademark, manufacturer, or otherwise, does not necessarily constitute or imply its endorsement, recommendation, or favoring by the United States Government or any agency thereof. The views and opinions of authors expressed herein do not necessarily state or reflect those of the United States Government or any agency thereof. 
Nuclear Science and Technology Division

\section{CAUSTIC-SIDE SOLVENT EXTRACTION SOLVENT-COMPOSITION RECOMMENDATION}

L. N. Klatt, J. F. Birdwell, Jr., P. V. Bonnesen, ${ }^{1}$ L. H. Delmau, ${ }^{1}$ L. J. Foote, ${ }^{1}$ D. D. Lee, R. A. Leonard, ${ }^{2}$ T. G. Levitskaia, ${ }^{1}$

M. P. Maskarinec, ${ }^{1}$ and B. A. Moyer ${ }^{1}$

${ }^{1}$ Chemical Sciences Division, ORNL

${ }^{2}$ Chemical Technology Division, Argonne National Laboratory

Date Published: January 2001

Prepared for the

Office of Project Completion, Environmental Management,

U.S. Department of Energy

and

the Tanks Focus Area, Office of Science and Technology,

Salt Processing Program, U.S. Department of Energy

Prepared by the

OAK RIDGE NATIONAL LABORATORY

Oak Ridge, Tennessee 37831-6285

managed by

UT-BATTELLE, LLC

for the

U.S. DEPARTMENT OF ENERGY

under contract DE-AC05-00OR22725 


\section{CONTENTS}

Page

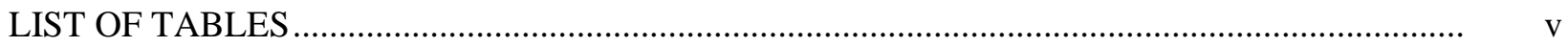

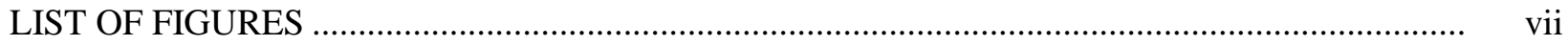

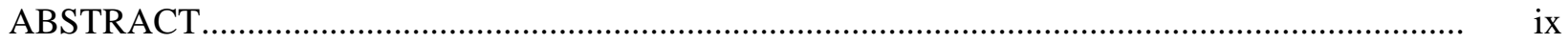

1. BASIS FOR TASK AND SUMMARY RECOMMENDATION ….........................................

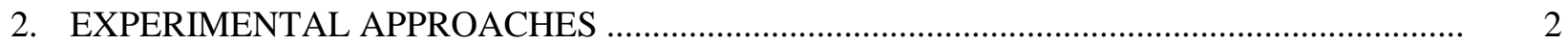

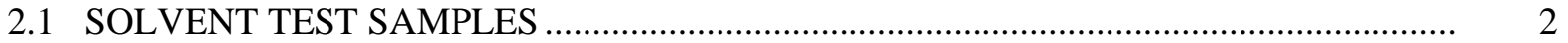

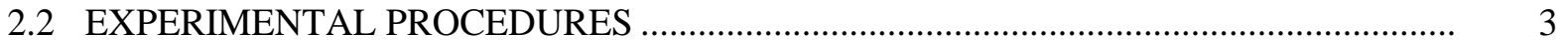

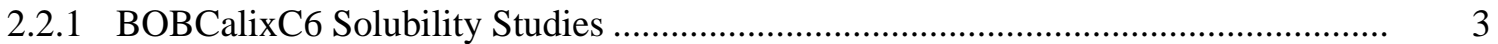

2.2.2 Extraction, Scrub, and Strip Protocol …................................................................ 4

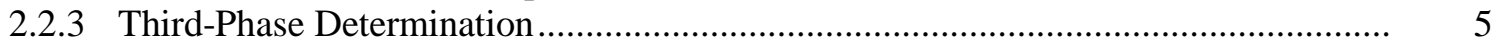

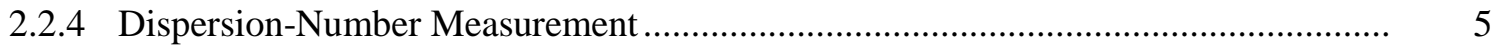

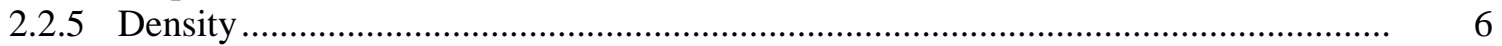

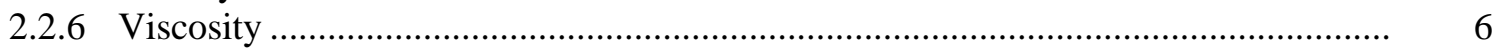

2.2.7 Surface Tension and Interfacial Tension .................................................................... 7

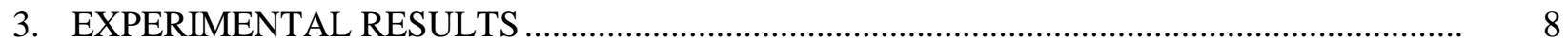

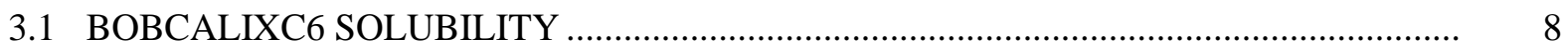

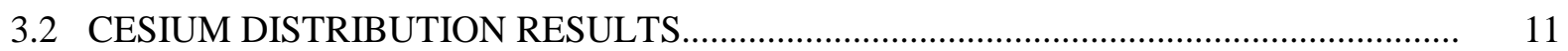

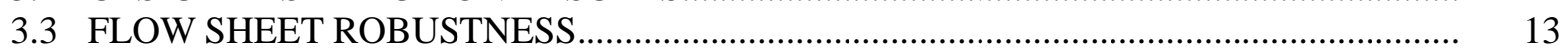

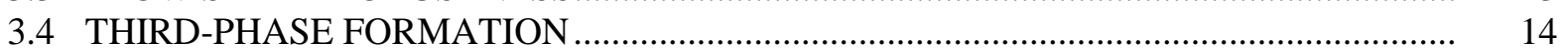

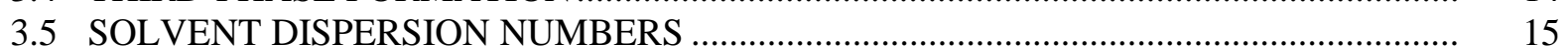

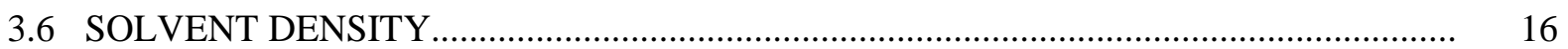

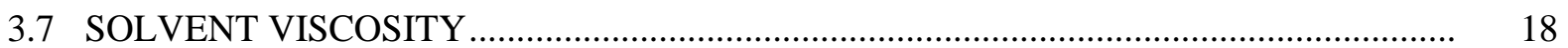

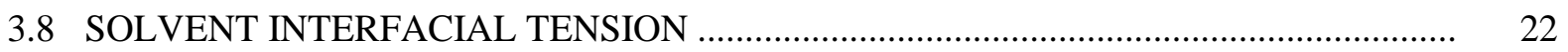

4. SOLVENT COMPOSITION RECOMMENDATION PROCESS ............................................... 25

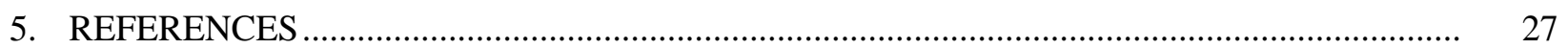

Appendix A. PREDICTED D $\mathrm{C}_{\mathrm{Cs}}$ VALUES USING THE log VERSUS log RELATIONSHIPS BETWEEN D ${ }_{\mathrm{Cs}}$ VALUES AND BOBCALIXC6 AND Cs-7SB

MODIFIER CONCENTRATIONS. 


\section{LIST OF TABLES}

Table

Page

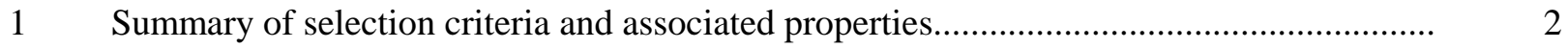

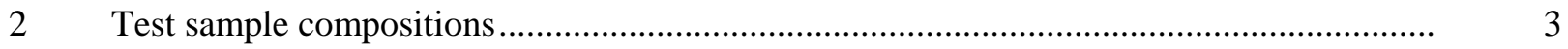

$3 \quad$ Validation data for the modified ESS protocol .........................................................

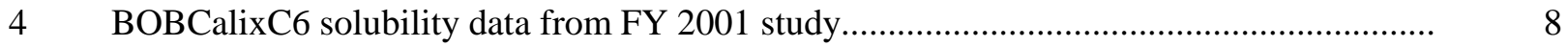

$5 \quad$ BOBCalixC6 solubility data from FY 2000 study ...................................................... 10

$6 \quad$ ESS results obtained with constant TOA concentration..................................................... 11

$7 \quad$ ESS results obtained with two selected solvents with variable TOA concentrations ........... 12

$8 \quad$ Calculated robustness for various CSSX solvent compositions ........................................ 14

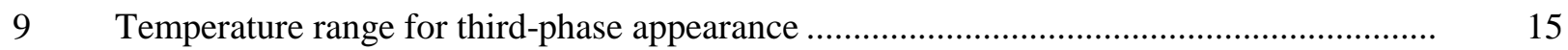

10 Dispersion numbers for extraction, scrub, and stripping of CSSX solvents ….................. 16

11 Dispersion numbers for washing of CSSX solvents B001107-3-4 and B001107-3-5......... 18

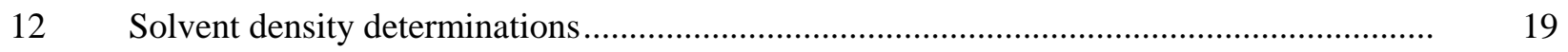

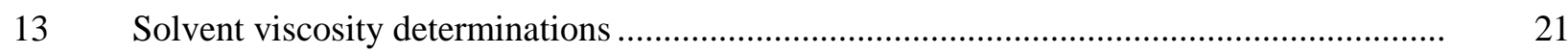

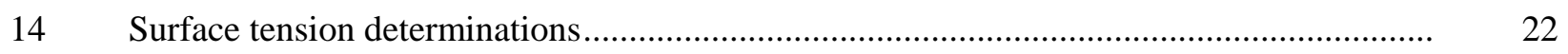

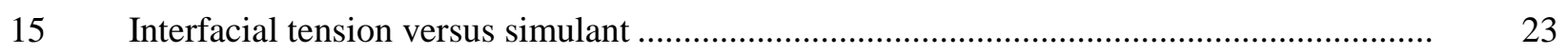

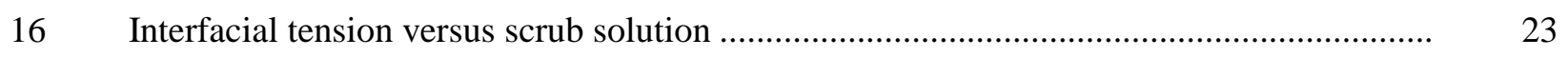

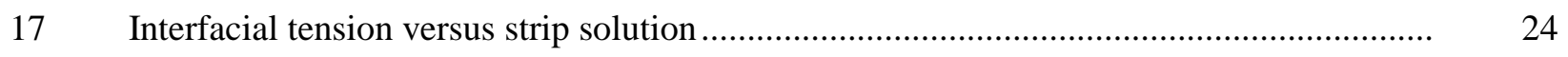

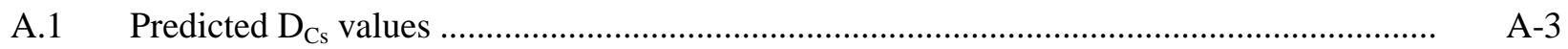




\section{LIST OF FIGURES}

Figure

Page

1 Comparison of BOBCalixC6 solubility data. The circles correspond to solubility tests performed by dissolution with recrystallized calixarene; the triangles correspond to solubility tests performed by precipitation with calixarene used as-received

2 CSSX solvent dispersion numbers for extraction, scrub, and strip conditions at baseline $\mathrm{O}: \mathrm{A}$ ratios

3 CSSX solvent dispersion numbers for solvent wash with dilute $\mathrm{NaOH}$

4 CSSX solvent dispersion numbers for solvent wash conditions as a function of $\mathrm{NaOH}$ concentration

5 CSSX solvent density as a function of Cs-7SB modifier concentration for $25.6^{\circ} \mathrm{C}$

6 Solvent viscosity as a function of temperature. The numbers in the legend are the test numbers from Table 2

7 Solvent shear stress as a function of temperature. The solvent numbers in the legend are the test numbers from Table 2

8 Solvent and process solution surface tension. The numbers on the abscissa are the test numbers from Table 2

9 Solvent interfacial tension in extraction, scrub, and strip contacts. The numbers on the abscissa are the test numbers from Table 2 


\begin{abstract}
The U.S. Department of Energy has selected caustic-side solvent extraction as the preferred cesium removal technology for the treatment of high-level waste stored at the Savannah River Site. Data for the solubility of the extractant, calix[4]arene-bis(tert-octyl benzo-crown-6), acquired and reported for the Salt Processing Program down-select decision, showed the original solvent composition to be supersaturated with respect to the extractant. Although solvent samples have been observed for approximately 1 year without any solids formation, work was completed to define a new solvent composition that was thermodynamically stable with respect to solids formation and to expand the operating temperature with respect to third-phase formation. Chemical and physical data as a function of solvent component concentrations were collected. The data included calix[4]arene-bis(tert-octyl benzo-crown-6) solubility; cesium distribution ratio under extraction, scrub, and strip conditions; flow sheet robustness; temperature range of third-phase formation; dispersion numbers for the solvent against waste simulant, scrub and strip acids, and sodium hydroxide wash solutions; solvent density; viscosity; and surface and interfacial tension. These data were mapped against a set of predefined performance criteria. The composition of $0.007 M$ calix[4]arene-bis(tert-octyl benzo-crown-6), $0.75 M$ 1-(2,2,3,3-tetrafluoropropoxy)-3-(4-secbutylphenoxy)-2-propanol, and $0.003 M$ tri- $n$-octylamine in the diluent Isopar® $\mathrm{L}$ provided the best match between the measured properties and the performance criteria. Therefore, it is recommended as the new baseline solvent composition.
\end{abstract}




\section{BASIS FOR TASK AND SUMMARY RECOMMENDATION}

The purpose of this report is to provide the experimental information that forms the basis for a recommended change in the baseline composition of the caustic-side solvent extraction (CSSX) solvent. The current baseline CSSX solvent composition is $0.010 M$ calix[4]arene-bis(tert-octyl benzo-crown-6), known as BOBCalixC6; 0.5 M 1-(2,2,3,3-tetrafluoropropoxy)-3-(4-sec-butylphenoxy)-2-propanol, known as Cs-7SB modifier; and $0.001 M$ tri-n-octylamine (TOA) in the diluent Isopar ${ }^{\circledR}$ L. ${ }^{1}$ Data for the solubility of BOBCalixC6 acquired and reported for the Salt Processing Program (SPP) alternative technology down-select decision showed that the above composition is supersaturated with respect to BOBCalixC6. ${ }^{2}$ Although samples of the baseline solvent have been observed for approximately 1 year without any solids formation, the CSSX technical team recommended that a solvent-composition optimization task be undertaken to address the BOBCalixC6 solubility and other issues, ${ }^{3}$ such as thirdphase formation, as a function of the plant operating temperature.

To accomplish the task of recommending a new baseline solvent composition, the CSSX technical team and the Tanks Focus Area (TFA) and SPP management teams, in cooperation with the U.S. Department of Energy-Savannah River (DOE-SR), developed an experimental program designed to provide the required information. Part of this effort included the development of the solvent-composition selection criteria. ${ }^{4}$

The recommendation for the new solvent composition is a consensus opinion of the CSSX technical team. The recommended composition is as follows:

- $\quad 0.007 M$ BOBCalixC6,

- $\quad 0.75 M$ Cs-7SB modifier,

- $0.003 M$ TOA, and

- Isopar® L diluent.

Table 1 contains a summary of the bounding and goal selection criteria and the value of the experimental property for the respective criterion for the recommended solvent composition.

It should be noted that the criteria dealing with the change in the cesium distribution ratio $\mathrm{D}_{\mathrm{Cs}}$ values as a function of solvent composition (i.e., solvent robustness) and the cost of solvent components did not enter into the decision process. These two criteria were intended to be used if the other criteria identified multiple acceptable compositions. 
Table 1. Summary of selection criteria and associated properties

\begin{tabular}{|c|c|c|c|}
\hline Criterion & Bounding condition & Goal condition & Value of property \\
\hline BOBCalixC6 solubility & Thermodynamically stable & Thermodynamically stable & $\geq 7.55 \mathrm{~m} M$ at $25^{\circ} \mathrm{C}$ \\
\hline $\mathrm{D}_{\mathrm{Cs}}$ values & 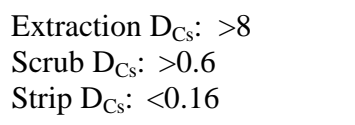 & $\begin{array}{l}\text { Extraction } \mathrm{D}_{\mathrm{Cs}}:>17.8 \\
\text { Scrub } \mathrm{D}_{\mathrm{Cs}}:>1.6 \\
\text { Strip } \mathrm{D}_{\mathrm{Cs}}:<0.15\end{array}$ & $\begin{array}{l}\text { Extraction } D_{C s}=14.1 \\
\text { Scrub } D_{C s}=1.3 \\
\text { Strip } D_{C s}=0.10\end{array}$ \\
\hline Flow sheet robustness & 1.0 & 3.0 & $>8.0$ \\
\hline Third-phase formation & $\begin{array}{l}15 \leq \mathrm{T} \leq 35^{\circ} \mathrm{C} \\
\text { at }\left[\mathrm{K}^{+}\right]=0.05 \mathrm{M}\end{array}$ & $\begin{array}{l}15 \leq \mathrm{T} \leq 35^{\circ} \mathrm{C} \\
\text { at }\left[\mathrm{K}^{+}\right]=0.05 \mathrm{M}\end{array}$ & $\begin{array}{l}<10^{\circ} \mathrm{C} \\
\text { at }\left[\mathrm{K}^{+}\right]=0.05 \mathrm{M}\end{array}$ \\
\hline $\begin{array}{l}\text { Dispersion number against } \\
\text { simulant, scrub, and strip solutions }\end{array}$ & $>4.0 \mathrm{E}-04$ & $>4.0 \mathrm{E}-04$ & $>5.0 \mathrm{E}-04$ \\
\hline $\begin{array}{l}\text { Dispersion number against } \mathrm{NaOH} \\
\text { wash solution }\end{array}$ & $>4.0 \mathrm{E}-04$ & $>4.0 \mathrm{E}-04$ & $\begin{array}{l}>4.5 \mathrm{E}-04 \\
\text { at } 0.3 \mathrm{M} \mathrm{NaOH}\end{array}$ \\
\hline Solvent density & $\leq 0.90 \mathrm{~g} / \mathrm{mL}$ at $25^{\circ} \mathrm{C}$ & $\leq 0.86 \mathrm{~g} / \mathrm{mL}$ at $25^{\circ} \mathrm{C}$ & $0.85 \mathrm{~g} / \mathrm{mL}$ at $25.6^{\circ} \mathrm{C}$ \\
\hline
\end{tabular}

\section{EXPERIMENTAL APPROACHES}

\subsection{SOLVENT TEST SAMPLES}

A total of 13 test samples of solvent were prepared for this study. The compositions of these samples are given in Table 2. A sample of the baseline solvent was included for reference purposes. Single lots of modifier (Lot No. PVB B000894-48P) and BOBCalixC6 (Lot No. IBC 000714HMKC-0004) were used to prepare all of the test samples. Solvents containing 3 and $10 \mathrm{~m} M$ TOA were prepared by adding a measured amount of $0.2 \mathrm{M}$ TOA in Isopar® $\mathrm{L}$ to the solvents originally prepared with $1 \mathrm{~m} M$ TOA. All solvents were washed twice with $0.1 \mathrm{M} \mathrm{NaOH}$, twice with $0.05 M \mathrm{HNO}_{3}$, three times with deionized water, and allowed to stand overnight before being decanted into clean containers. Scrub $\left(0.05 M \mathrm{HNO}_{3}\right)$ and strip $\left(0.001 \mathrm{M} \mathrm{HNO}_{3}\right)$ solutions were prepared by diluting commercially available stock solutions with deionized water. Sodium hydroxide solutions were prepared by diluting a commercially available standard solution. Savannah River Site (SRS) waste supernatant simulant was formulated according to the SRS procedure. ${ }^{5}$ The nominal cesium concentration in all the simulant batches used in the testing was $0.00014 M$. Aliquots of the solvent were transferred to the Nuclear Science and Technology Division (NSTD) at Oak Ridge National Laboratory (ORNL) for measurements of dispersion number, viscosity, density, surface tension, and interfacial tension. Other measurements, plus the initial solvent preparation, were carried out in the ORNL Chemical Sciences Division (CSD). 
Table 2. Test sample compositions

\begin{tabular}{ccccc}
\hline Solvent identification & Test no. & BOBCalixC6 $(\mathrm{m} M)$ & Cs-7SB modifier $(M)$ & TOA $(\mathrm{m} M)$ \\
\hline Current baseline & 1 & 10 & 0.50 & 1 \\
B001107-3-1 & 1 & 8 & 0.65 & 1 \\
B001107-3-2 & 2 & 10 & 0.65 & 1 \\
B001107-3-3 & 3 & 8 & 0.75 & 1 \\
B001107-3-4 & 4 & 6 & 0.75 & 1 \\
B001107-3-5 & 5 & 8 & 0.75 & 1 \\
B001107-3-6 & 6 & 6 & 0.85 & 1 \\
B001107-3-7 & 7 & 8 & 0.85 & 1 \\
B001107-3-8 & 8 & 6 & 1.00 & 1 \\
B001107-3-9 & 9 & 8 & 1.00 & 3 \\
B001107-3-2A & 10 & 8 & 0.65 & 10 \\
B001107-3-2B & 11 & 8 & 0.65 & 3 \\
B001107-3-4C & 12 & 13 & 0.75 & 10 \\
B001107-3-4D & & 8 & 0.75 & 1 \\
\hline
\end{tabular}

\subsection{EXPERIMENTAL PROCEDURES}

\subsubsection{BOBCalixC6 Solubility Studies}

A series of solvents were prepared from five different pristine nonwashed solutions of Cs-7SB modifier in Isopar® $\mathrm{L}(0.5,0.65,0.75,0.85$, and $1.0 M)$ containing $1 \mathrm{~m} M$ TOA as follows. Three and one-half grams of BOBCalixC6 (Lot 000714 HMKC-0004) was dissolved in $50 \mathrm{~mL}$ of modifier solution in Isopar® L by applying sonication and heating to about $50^{\circ} \mathrm{C}$, cooling to room temperature, and then seeding with about $2 \mathrm{mg}$ of recrystallized BOBCalixC6. The samples were then shaken and divided into six samples of equal volume. Samples in duplicate were placed in a water bath at $15^{\circ} \mathrm{C}$, an air box at $25^{\circ} \mathrm{C}$, and an incubator at $35^{\circ} \mathrm{C}$. Agitation was effected by shaking in the water bath and wheel rotation in the air box and incubator. The initial concentration of BOBCalixC6 in each sample was $59 \mathrm{~m} M$. After a given time interval, the samples were allowed to settle for 30 to $60 \mathrm{~min}$, whereupon an aliquot of the 
supernatant solution was withdrawn, filtered through No. 40 filter paper, diluted with chloroform, and submitted for high-performance liquid chromatography (HPLC) analysis. Samples archived from the solubility study initiated approximately 1 year $\mathrm{ago}^{2}$ were also analyzed.

\subsubsection{Extraction, Scrub, and Strip Protocol}

Extraction, scrub, and strip (ESS) tests were performed on all of the samples listed in Table 2. The experiments were conducted following the protocol defined in Ref. 2, using organic:aqueous volume ratios (O:A) of 1:3 on extraction and 5:1 on scrubs and strips. An extra scrub step was added to the previous protocol ${ }^{2}$ to more realistically approximate the flow sheet. It should be noted that the solvent weakly extracts sodium and potassium, and the second scrub step more completely removes these metals from the solvent prior to stripping. With only one scrub, the first strip step is expected to yield slightly higher values of $\mathrm{D}_{\mathrm{Cs}}$ because the incomplete scrubbing of sodium and potassium implies that these metal nitrates will report to the aqueous phase of the first strip step, thereby increasing the aqueous-phase nitrate concentration. The data validating the modified ESS protocol are given in Table 3. The data confirm that addition of the second scrub improves stripping performance as expected. The $\mathrm{D}_{\mathrm{Cs}}$ values are slightly dependent on the O:A ratios employed, with better performance occurring when the strip O:A ratio is lower. All stripping $\mathrm{D}_{\mathrm{Cs}}$ values converge to the same value upon successive stripping. In the solventoptimization tests, an increase in modifier concentration is expected to increase sodium and potassium extraction. ${ }^{2}$ However, the consequent negative impact on stripping is expected to be essentially eliminated by the second scrub and thus appropriately rendered an insignificant factor in solvent selection.

Table 3. Validation data for the modified ESS protocol

\begin{tabular}{|c|c|c|c|c|}
\hline & \multicolumn{4}{|c|}{ Value of $\mathrm{D}_{\mathrm{Cs}}$ by O:A ratios ${ }^{a}$} \\
\hline & $\begin{array}{c}1: 3(\mathrm{E}) \\
5: 1(\mathrm{SS})\end{array}$ & $\begin{array}{c}1: 5(\mathrm{E}) \\
3: 1(\mathrm{SS})\end{array}$ & $\begin{array}{c}1: 3(\mathrm{E}) \\
5: 1(\mathrm{SS})\end{array}$ & $\begin{array}{c}1: 5(\mathrm{E}) \\
3: 1(\mathrm{SS})\end{array}$ \\
\hline Extraction & 17.6 & 17.1 & 16.6 & 17.3 \\
\hline Scrub no. 1 & 1.55 & 1.57 & 1.56 & 1.57 \\
\hline Scrub no. 2 & NA & NA & 1.56 & 1.57 \\
\hline Strip no. 1 & 0.137 & 0.130 & 0.120 & 0.116 \\
\hline Strip no. 2 & 0.080 & 0.075 & 0.078 & 0.071 \\
\hline Strip no. 3 & 0.064 & 0.064 & 0.062 & 0.062 \\
\hline Strip no. 4 & 0.052 & 0.054 & 0.052 & 0.054 \\
\hline
\end{tabular}

${ }^{a}$ The letter "E" denotes O:A ratio for extraction; "SS" denotes O:A ratio for scrub and strip. 


\subsubsection{Third-Phase Determination}

Third-phase formation experiments involved the ten solvents containing $1 \mathrm{~m} M$ of TOA and three different simulants: baseline simulant $\left(\left[\mathrm{Cs}^{+}\right]=0.14 \mathrm{mM},\left[\mathrm{K}^{+}\right]=0.02 \mathrm{M}\right)$; high-potassium simulant $\left(\left[\mathrm{Cs}^{+}\right]=0.14 \mathrm{~m} M,\left[\mathrm{~K}^{+}\right]=0.05 M\right)$; and high-potassium, high-cesium simulant $\left(\left[\mathrm{Cs}^{+}\right]=0.44 \mathrm{~m} M,\left[\mathrm{~K}^{+}\right]=\right.$

$0.05 \mathrm{M}$ ). These conditions encompass those that could be potentially encountered with real wastes. ${ }^{1}$ After two repeated contacts with the simulants $(\mathrm{O}: \mathrm{A}=1: 3)$ at $25^{\circ} \mathrm{C}$, the solvent samples were cooled in a water bath and shaken periodically. The presence and/or absence of a third phase was determined by independent examination by two researchers.

\subsubsection{Dispersion-Number Measurement}

Dispersion numbers were determined under extraction, scrubbing, and stripping conditions in the presence of cesium. Prior to use, all new or previously used glassware and plastic vessels were washed by rinsing with tap water three times, rinsing with demineralized water three times, rinsing with ethanol two times, and rinsing with acetone two times. The equipment was allowed to air dry or was dried with a stream of dry nitrogen or argon before use. In all tests, phase volumes proportional to the flow rates of the solvent, scrub, and strip solutions in the CSSX baseline flow sheet were placed into a 100-mL graduated Pyrex ${ }^{\circledR}$ cylinder. The position of the interface was recorded. The cylinder was capped with a ground-glass stopper, and the solutions were agitated for $20 \mathrm{~s}$. Agitation was suspended for $10 \mathrm{~s}$ and then resumed for an additional $20 \mathrm{~s}$. At the end of the second agitation, a stopwatch was started and the time required for the interface to return to its original position was recorded. In these tests, the "original" position was assumed to be that within 1-2 mm of the interface prior to the agitation and when all indications of dispersed phases at the interface had disappeared. The total height of the dispersion within the cylinder was measured. Each determination was repeated three times. Dimensionless dispersion numbers were calculated according to the expression ${ }^{6}$

$$
N_{D i}=\frac{1}{t_{b}} \sqrt{\frac{z}{g_{c}}},
$$

where $t_{b}$ is the break time in seconds, $\mathrm{z}$ is the dispersion band height in centimeters, and $\mathrm{g}_{c}$ is the gravitational force of $981 \mathrm{~cm} / \mathrm{s}^{2}$. 


\subsubsection{Density}

The solvent densities were measured using procedures based on ASTM D891 ${ }^{7}$ and ASTM D1429, ${ }^{8}$ using new 50-mL class A borosilicate glass volumetric flasks with ground-glass stoppers. Calibration of the volumetric flasks for density measurements was performed based on ASTM E542. ${ }^{9}$ A Mettler AE260 analytical balance (S/N J19097) capable of measuring to $0.1 \mathrm{mg}$ was used to weigh the flasks. National Institute of Standards and Technology (NIST)-based test weights were used to check the balance calibration. A thermometer accurate to $0.1^{\circ} \mathrm{C}$ (LaPine 398-12-53) was used to measure the temperature of the liquid in the flasks. The flasks were cleaned and dried before each use as described above, using tap water, deionized water, ethanol, and acetone, followed by drying with argon gas. Each flask was filled using a $10-\mathrm{mL}$ transfer pipette to just below the line and then adjusted to the line with a small transfer pipette. The actual volume of each flask was calculated from the weight of the water contained.

\subsubsection{Viscosity}

The viscosities of each of the nine candidate solvents and the original solvent were measured at 20, 25, 30, 35, and $40^{\circ} \mathrm{C}$ using procedures adapted from ASTM D2196 ${ }^{10}$ and the Brookfield viscometer operating instructions. ${ }^{11}$ The determinations were made using a Brookfield rotational viscometer, model LVTDV-II, serial number D15869, with a UL adapter. The water jacket on the UL adapter was heated and cooled by a VWR model 13270-615 circulation bath, with 190-Ws cooling, and operated at a coolant recirculation rate of $\sim 2 \mathrm{~L} / \mathrm{min}$. It contained a 50/50 mixture of ethylene glycol and water, which was circulated by the water bath circulation pump. The thermometer used, the LaPine 398-12-53, was immersed in the water bath for the temperature measurement. (There is no room in the UL adapter for a thermometer.) The spindle speed was set to give a torque percent reading in the middle or upper portion of the scale. The UL adapter (a large-diameter spindle in a cylindrical container just slightly larger in diameter than the spindle) is used for measuring low-viscosity liquids (liquids with viscosities between 1 and $20 \mathrm{cP}$ ). The UL adapter with spindle holds $16 \mathrm{~mL}$ of sample for measurement.

Each test was begun by adding the test solvent to the UL adapter, installing it on the viscometer, starting the spindle rotation at $60 \mathrm{rpm}$, and then setting the temperature bath to $20^{\circ} \mathrm{C}$. After the temperature had stabilized for several minutes, the viscosity of the sample was measured. The temperature bath was then adjusted to the next temperature and the system temperature allowed to stabilize before the next reading was taken. 


\subsubsection{Surface Tension and Interfacial Tension}

The surface tensions of each of the nine candidate solvents, the original solvent, simulant, strip solution, and scrub solution were measured at $\sim 25^{\circ} \mathrm{C}$ using a CSC Du Nouy tensiometer (serial number 013457) with a 6-cm-circumference ring. The experimental procedures were adapted from ASTM D971 ${ }^{12}$ and ASTM D1331. ${ }^{13}$ The tensiometer was calibrated against known weights and its zero point adjusted according to the procedure of the manufacturer. Interfacial tension was determined by measuring the force necessary to detach a planar ring of platinum wire from the surface of the liquid of higher surface tension, that is, upward from the aqueous-organic interface. To calculate the interfacial tension, the force so measured was corrected by an empirically determined factor that depends upon the force applied, the densities of both organic and aqueous layers, and the dimensions of the ring. Measurements are made under rigidly standardized nonequilibrium conditions in which the measurement is completed within $60 \mathrm{~s}$ after formation of the interface. The surface tension of deionized water was measured to determine that the apparatus was functioning correctly. A value of $71-73 \mathrm{dyn} / \mathrm{cm}$ must be obtained; the literature value at $25^{\circ} \mathrm{C}$ is $72.0 \mathrm{dyn} / \mathrm{cm} .{ }^{14}$

A Teflon ${ }^{\mathrm{TM}}$ sample container having a minimum diameter of $45 \mathrm{~mm}$ was used. The container was cleaned as described above (with tap water, deionized water, ethanol, and acetone) between each solvent/aqueous determination. The ring was then flamed in a blue gas flame, using spinning to obtain rapid, uniform heating. The ring should barely glow orange and should be heated for no more than $5 \mathrm{~s}$.

Interfacial tension measurements were made by carefully placing a layer of the organic on the surface of the aqueous layer (the aqueous layer was placed in the container first and the ring submerged in this layer) until a depth of at least $10 \mathrm{~mm}$ was reached using a pipette. This procedure was used to ensure that minimum mixing occurred and that the organic did not touch the surface of the submerged ring. The organic-aqueous interface was allowed to age for $30 \pm 1 \mathrm{~s}$ after the last of the organic had been layered onto the water. The platform was lowered and the value at rupture recorded. The measurement was timed so that, as nearly as possible, $30 \mathrm{~s}$ was required to draw the ring through the interface. The entire operation, from the time of pouring the organic onto the aqueous until the interface ruptured, was completed in about $60 \pm 10 \mathrm{~s}$. Each solvent was tested in duplicate, with the cup and the ring cleaned between the two readings.

The interfacial tension of the sample was calculated by means of the following equation:

$$
\text { Interfacial tension, } \mathrm{dyn} / \mathrm{cm}=P \times \mathrm{F} \text {, }
$$

where $P$ is the scale reading when the film ruptures (in dynes per centimeter), and $\mathrm{F}$ is the factor converting the scale reading (in dynes per centimeter) to interfacial tension, as obtained from Eq. (3). The 
value of the diameter ratio, $R / r$, for the ring, as specified by the manufacturer, is 53.6. The value of $\mathrm{F}$ is obtained as follows:

$$
\mathrm{F}=0.7250+\left[0.01452 \mathrm{P} / \mathrm{C}^{2}(\mathrm{D}-\mathrm{d})+0.04534-1.679 /(R / r)\right]^{1 / 2},
$$

where $\mathrm{C}$ is the circumference of the ring $(5.992 \mathrm{~cm})$; $\mathrm{D}$ is the density of the aqueous layer at $25^{\circ} \mathrm{C}$, in grams per milliliter; $\mathrm{d}$ is the density of organic layer for interfacial testing at $25^{\circ} \mathrm{C}$, in grams per milliliter; $R$ is the radius of ring, in centimeters; and $r$ is the radius of the wire of the ring, in centimeters.

\section{EXPERIMENTAL RESULTS}

\subsection{BOBCALIXC6 SOLUBILITY}

The data on the BOBCalixC6 are a combination of information acquired from the experiments conducted in the latter portion of FY 2001 (see Experimental Section) and from the previous experiment reported in Ref. 2. This summary of the experimental results is necessary because of the long periods of time required for the BOBCalixC6 to achieve the solubility equilibrium condition. Table 4 summarizes the data obtained from the most recent solubility study.

Table 4. BOBCalixC6 solubility data from FY 2001 study $^{a}$

\begin{tabular}{|c|c|c|c|c|c|c|c|c|c|}
\hline \multirow[b]{3}{*}{ Cs-7SB $(M)$} & \multicolumn{9}{|c|}{ BOBCalixC6 $(\mathrm{m} M)$} \\
\hline & \multicolumn{3}{|c|}{$15^{\circ} \mathrm{C}$} & \multicolumn{3}{|c|}{$25^{\circ} \mathrm{C}$} & \multicolumn{3}{|c|}{$35^{\circ} \mathrm{C}$} \\
\hline & Initial & 4 wks & 8 wks & Initial & 4 wks & 8 wks & Initial & 4 wks & 8 wks \\
\hline 0.50 & 59 & 17.5 & 8.80 & 59 & 11.7 & 10.7 & 59 & 9.5 & 7.94 \\
\hline 0.65 & 59 & 22.9 & 11.5 & 59 & 17.3 & 14.0 & 59 & 12.9 & 9.72 \\
\hline 0.75 & 59 & 35.0 & 15.2 & 59 & 19.7 & 13.1 & 59 & 15.4 & 11.2 \\
\hline 0.85 & 59 & 45.6 & 18.3 & 59 & 35.7 & 15.9 & 59 & 20.5 & 14.7 \\
\hline 1.0 & 59 & 49.5 & 25.7 & 59 & 54.1 & 23.1 & 59 & 44.7 & 19.0 \\
\hline
\end{tabular}

${ }^{a}$ Each value is the average of duplicate analyses.

The time trend analysis of the data shows that after 8 weeks, solubility equilibrium has not been achieved. Nevertheless, the data imply the supersaturation of the baseline solvent. 
A conservative estimate of the lower bound of the BOBCalixC6 solubility at $25^{\circ} \mathrm{C}$ was obtained by reanalysis of samples from the solubility study that was initiated approximately 1 year ago. ${ }^{2}$ These samples had been stored at temperature with intermittent agitation. Selected results are summarized in Fig. 1. As indicated in the legend, data are shown for both as-received and recrystallized BOBCalixC6 and for equilibrium approached from the direction of both dissolution and precipitation. In each case, no TOA or water is present in the solvent; that is, solid BOBCalixC6 is suspended in Cs-7SB at the indicated concentration in Isopar® L only. A tabulation of the data after 1 year, including systems containing TOA and water, is given in Table 5. Except for the single data point at $0.25 M$ Cs-7SB, which shows a deviation of $\pm 26 \%$, the average analytical deviation among duplicate samples is $\pm 3.5 \%$. The data show that TOA and water have little or no effect on BOBCalixC6 solubility.

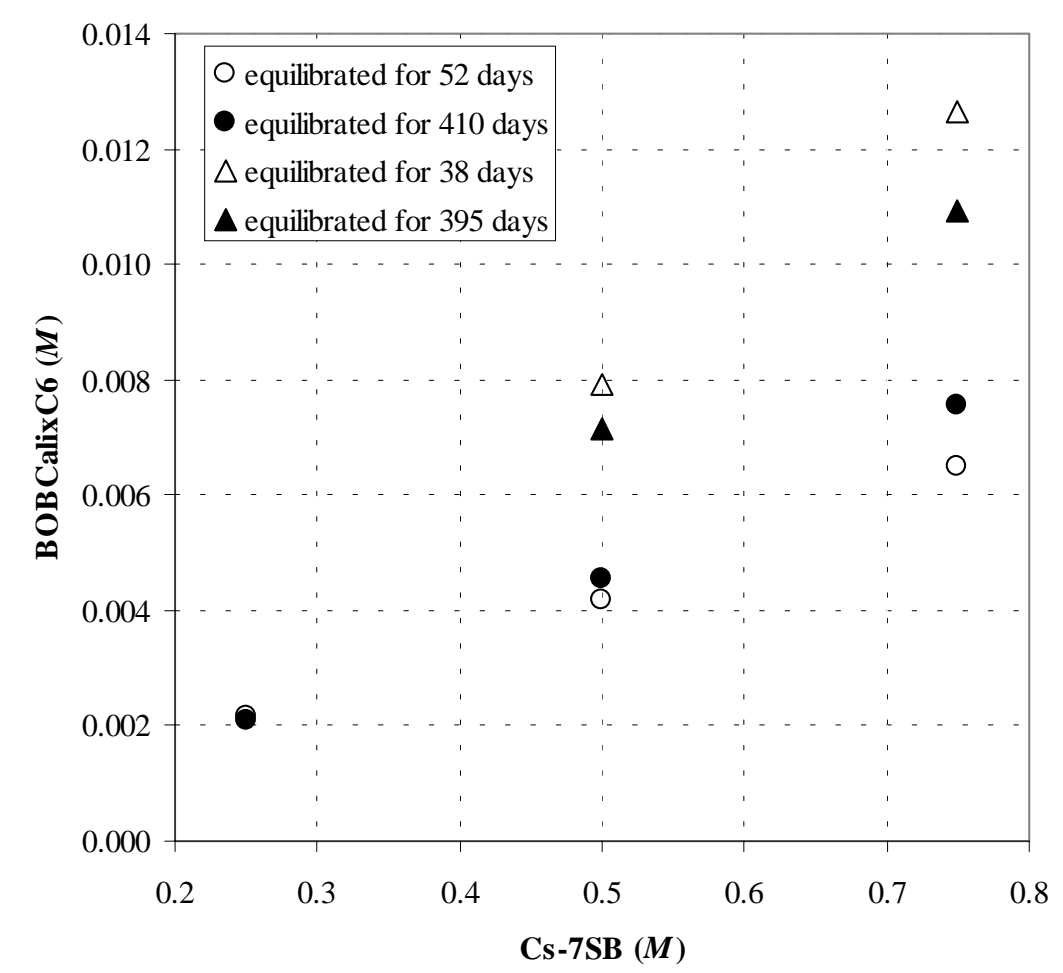

Fig. 1. Comparison of BOBCalixC6 solubility data. The circles correspond to solubility tests performed by dissolution with recrystallized calixarene; the triangles correspond to solubility tests performed by precipitation with calixarene used as-received.

Conservatively, the lower bound of the BOBCalixC6 thermodynamic solubility corresponds to the recrystallized $\mathrm{BOBCalixC6}$ that has been dissolving over the course of the past 13 months. At $0.75 \mathrm{M}$ Cs-7SB, the lower bound at $25^{\circ} \mathrm{C}$ is $7.55 \mathrm{mM}$. Although the solubility of BOBCalixC6 generally 
increases with increasing Cs-7SB concentration, a gap exists between the data for the recrystallized BOBCalixC6 that is dissolving and the as-received BOBCalixC6 that is precipitating.

Table 5. BOBCalixC6 solubility data from FY 2000 study $^{a}$

\begin{tabular}{|c|c|c|c|c|c|c|c|}
\hline $\begin{array}{l}\text { Sample } \\
\text { no. }\end{array}$ & $\begin{array}{l}\text { Cs-7SB } \\
(M)\end{array}$ & $\begin{array}{l}\text { TOA } \\
(\mathrm{m} M)\end{array}$ & $\begin{array}{c}\text { Solvent } \\
\text { washed? }\end{array}$ & $\begin{array}{l}\text { Dissolution } \\
\text { method }\end{array}$ & $\begin{array}{l}\text { BOBCalixC6 } \\
\text { purification }\end{array}$ & $\begin{array}{c}\text { BOBCalixC6 } \\
(\mathrm{m} M)\end{array}$ & $\begin{array}{l}\text { BOBCalixC6 } \\
\text { average }(\mathrm{m} M)\end{array}$ \\
\hline $5-\mathrm{A}$ & 0.25 & 0 & No & Dissolve & Recrystallized & 2.62 & \\
\hline $5-\mathrm{B}$ & 0.25 & 0 & No & Dissolve & Recrystallized & 1.55 & 2.08 \\
\hline $6-\mathrm{A}$ & 0.50 & 0 & No & Dissolve & Recrystallized & 4.31 & \\
\hline $6-\mathrm{B}$ & 0.50 & 0 & No & Dissolve & Recrystallized & 4.76 & 4.54 \\
\hline 7-A & 0.75 & 0 & No & Dissolve & Recrystallized & 6.98 & \\
\hline $7-B$ & 0.75 & 0 & No & Dissolve & Recrystallized & 8.12 & 7.55 \\
\hline $8-\mathrm{A}$ & 0.50 & 1 & No & Dissolve & Recrystallized & 4.38 & \\
\hline 8-B & 0.50 & 1 & No & Dissolve & Recrystallized & 4.48 & 4.43 \\
\hline $9-\mathrm{A}$ & 0.50 & 1 & Yes & Dissolve & Recrystallized & 4.26 & \\
\hline $9-\mathrm{B}$ & 0.50 & 1 & Yes & Dissolve & Recrystallized & 4.64 & 4.45 \\
\hline $10-\mathrm{A}$ & 0.50 & 1 & No & Precipitate & Recrystallized & 6.18 & \\
\hline $10-\mathrm{B}$ & 0.50 & 1 & No & Precipitate & Recrystallized & 6.68 & 6.43 \\
\hline 11-A & 0.50 & 0 & No & Precipitate & As received & 7.26 & \\
\hline $11-B$ & 0.50 & 0 & No & Precipitate & As received & 7.05 & 7.15 \\
\hline $12-\mathrm{A}$ & 0.75 & 0 & No & Precipitate & As received & 11.1 & \\
\hline $12-\mathrm{B}$ & 0.75 & 0 & No & Precipitate & As received & 10.8 & 10.95 \\
\hline $13-\mathrm{A}$ & 0.50 & 0 & Yes & Precipitate & As received & 5.11 & \\
\hline 13-B & 0.50 & 0 & Yes & Precipitate & As received & & \\
\hline
\end{tabular}

${ }^{a} \mathrm{HPLC}$ analysis of samples held at $25^{\circ} \mathrm{C}$ for approximately 13 months.

From the data shown in Fig. 1, one may conclude that the true solubility of BOBCalixC6 in Isopar® L that contains only Cs-7SB at $25^{\circ} \mathrm{C}$ lies within this gap. Both sets of data show a very slow convergence over the course of the past year. The increases in solubility upon dissolution were 8.4 and $16.5 \%$ for 0.5 and $0.75 M$ Cs-7SB, respectively. The comparable decreases upon precipitation were 9.7 and $13.4 \%$ for 0.5 and $0.75 M$ Cs-7SB, respectively. At this time, it is impossible to determine conclusively whether the upper set differs from the lower set because of the purity of BOBCalixC6 or because of the direction from which equilibrium is being approached. However, we argue that the latter cause is more probable, because the high concentration of Cs-7SB likely negates any effects on solubility of minor impurities in the as-received BOBCalixC6. As discussed earlier, ${ }^{2}$ these impurities apparently have an effect on the rate of dissolution of BOBCalixC6. Whereas recrystallized BOBCalixC6 can be dissolved very slowly (even 
with prolonged sonication and warming), the as-received material, nominally $97 \%$ pure, quickly dissolves to concentrations as high as $50 \mathrm{~m} M$. For this reason, it has been impractical to experimentally approach equilibrium by precipitation of recrystallized BOBCalixC6. It is clear, then, that the lower bound of $7.55 \mathrm{~m} M$ BOBCalixC6 at $0.75 M$ Cs-7SB is a conservative estimate for the BOBCalixC6 solubility. Not only is the final plateau concentration of BOBCalixC6 likely to be higher, but the most realistic condition in a plant environment is for equilibrium to be approached by precipitation of the as-received material.

\subsection{CESIUM DISTRIBUTION RESULTS}

The cesium distribution data obtained with the ESS tests are summarized in Tables 6 and 7. The data in Table 6 are for the series of test samples containing $1 \mathrm{mM}$ TOA, and the results in Table 7 are for the series of test samples containing varying amounts of TOA and modifier with fixed BOBCalixC6 concentration.

Table 6. ESS results obtained with constant TOA concentration ${ }^{a}$

\begin{tabular}{ccccccccc}
\hline $\begin{array}{c}\text { BOBCalixC6 } \\
(\mathrm{m} M)\end{array}$ & $\begin{array}{c}\text { Cs-7SB } \\
(M)\end{array}$ & Extr. & $\begin{array}{c}\text { Scrub } \\
\text { no. 1 }\end{array}$ & $\begin{array}{c}\text { Scrub } \\
\text { no. 2 }\end{array}$ & $\begin{array}{c}\text { Strip } \\
\text { no. 1 }\end{array}$ & $\begin{array}{c}\text { Strip } \\
\text { no. 2 }\end{array}$ & $\begin{array}{c}\text { Strip } \\
\text { no. 3 }\end{array}$ & $\begin{array}{c}\text { Strip } \\
\text { no. 4 }\end{array}$ \\
\hline 10 & 0.50 & 17.2 & 1.52 & 1.52 & 0.114 & 0.070 & 0.055 & 0.051 \\
10 & 0.65 & 19.6 & 1.75 & 1.79 & 0.136 & 0.084 & 0.066 & 0.057 \\
10 & 0.75 & 20.7 & 1.91 & 1.91 & 0.152 & 0.092 & 0.072 & 0.062 \\
8 & 0.65 & 15.4 & 1.38 & 1.44 & 0.109 & 0.066 & 0.053 & 0.045 \\
8 & 0.75 & 16.1 & 1.52 & 1.54 & 0.120 & 0.075 & 0.056 & 0.050 \\
8 & 0.85 & 17.2 & 1.68 & 1.66 & 0.134 & 0.077 & 0.062 & 0.053 \\
8 & 1.00 & 17.7 & 1.87 & 1.78 & 0.145 & 0.086 & 0.069 & 0.060 \\
6 & & & & & & & & \\
6 & 0.75 & 12.2 & 1.12 & 1.16 & 0.089 & 0.051 & 0.042 & 0.036 \\
6 & 0.85 & 12.3 & 1.23 & 1.25 & 0.095 & 0.055 & 0.044 & 0.040 \\
\hline
\end{tabular}

${ }^{a}$ Temperature $=25^{\circ} \mathrm{C}$.

Interest in increasing the TOA concentration is twofold. First, as the TOA concentration increases, the CSSX process becomes more resistant to anionic impurities. Second, thermal ${ }^{2}$ and radiolytic ${ }^{15,16}$ stability test results showed that TOA is the solvent component most susceptible to decomposition. However, the concentration cannot be increased excessively, because the organic-phase concentration of nitrate in the scrub stage will increase by the protonation of TOA. This nitrate will be partially released in 
Table 7. ESS results obtained with two selected solvents with variable TOA concentrations ${ }^{a}$

\begin{tabular}{|c|c|c|c|c|c|c|c|}
\hline TOA $(\mathrm{m} M)$ & Extr. & $\begin{array}{c}\text { Scrub } \\
\text { no. } 1\end{array}$ & $\begin{array}{c}\text { Scrub } \\
\text { no. } 2\end{array}$ & $\begin{array}{l}\text { Strip } \\
\text { no. } 1\end{array}$ & $\begin{array}{l}\text { Strip } \\
\text { no. } 2\end{array}$ & $\begin{array}{l}\text { Strip } \\
\text { no. } 3\end{array}$ & $\begin{array}{l}\text { Strip } \\
\text { no. } 4\end{array}$ \\
\hline \multicolumn{8}{|c|}{ BOBCalixC6 $=8 \mathrm{~m} M$, Cs-7SB $=0.65 M$} \\
\hline 1 & 15.4 & 1.38 & 1.44 & 0.109 & 0.066 & 0.053 & 0.045 \\
\hline 3 & 14.9 & 1.08 & 1.39 & 0.116 & 0.081 & 0.069 & 0.056 \\
\hline \multirow[t]{2}{*}{10} & 14.7 & 1.00 & 0.76 & 0.134 & 0.104 & 0.090 & 0.076 \\
\hline & \multicolumn{7}{|c|}{ BOBCalixC6 $=8 \mathrm{~m} M$, Cs-7SB $=0.75 M$} \\
\hline 1 & 16.4 & 1.54 & 1.55 & 0.121 & 0.073 & 0.059 & 0.052 \\
\hline 3 & 15.5 & 1.26 & 1.49 & 0.124 & 0.083 & 0.075 & 0.059 \\
\hline 10 & 15.2 & 1.20 & 0.70 & 0.137 & 0.101 & 0.091 & 0.078 \\
\hline
\end{tabular}

${ }^{a}$ Temperature $=25^{\circ} \mathrm{C}$.

the first strip stage, causing the value of $\mathrm{D}_{\mathrm{Cs}}$ for the first strip stage to increase, which could ultimately limit the stripping effect. Assuming an O:A ratio of 5:1 in the strip section, the stripping effect becomes inhibited when the first strip $\mathrm{D}_{\mathrm{Cs}}$ value becomes equal to or greater than 0.2. The data show that stripping will not be inhibited at TOA concentrations as high as $10 \mathrm{mM}$.

The results show that values of $\mathrm{D}_{\mathrm{Cs}}$ for the two scrubs decrease as the concentration of TOA increases. This behavior is expected since the overall concentration of nitrate in the organic phase increases to ensure the electroneutrality of the protonated TOA. The $\mathrm{D}_{\mathrm{Cs}}$ values for the first strip also increase. Again, this result is expected because the higher concentration of protonated TOA in the organic phase results in more nitrates being released in the first strip stage. As a result of this higher nitrate concentration in the first strip stage, more stages are required for the $\mathrm{D}_{\mathrm{Cs}}$ value to converge to the limiting value. This limiting value should, in principle, be the same for all TOA concentrations.

Based on the cesium distribution ratio $\left(\mathrm{D}_{\mathrm{Cs}}\right)$ data contained in Tables 6 and 7 , all of the tested solvent compositions meet the $\mathrm{D}_{\mathrm{Cs}}$ acceptance criterion.

The $\mathrm{D}_{\mathrm{Cs}}$ values in Tables 6 and 7, when analyzed as $\log \left(\mathrm{D}_{\mathrm{Cs}}\right)$ vs $\log (\mathrm{BOBCalixC6}$ concentration) and $\log \left(\mathrm{D}_{\mathrm{Cs}}\right)$ vs $\log (\mathrm{Cs}-7 \mathrm{SB}$ modifier concentration), are linear with slopes approximately equal to one. Using these relationships, a simple set of equations can be used to predict the $\mathrm{D}_{\mathrm{Cs}}$ values as a function of the BOBCalixC6 and Cs-7SB modifier concentrations. The results of the prediction for BOBCalixC6 and modifier concentrations about the recommended solvent composition are given in Appendix A, Table A.1. 


\subsection{FLOW SHEET ROBUSTNESS}

A series of Spreadsheet Algorithm for Stagewise Solvent Extraction (SASSE) ${ }^{17}$ calculations were performed using the $\mathrm{D}_{\mathrm{Cs}}$ values contained in Tables 6 and 7. The assumptions used in these calculations include the following: (1) the extraction and scrub $\mathrm{D}_{\mathrm{Cs}}$ values are proportional to the concentration of free BOBCalixC6 in the organic phase; (2) the BOBCalixC6 is loaded with only one cesium ion; (3) the $\mathrm{D}_{\mathrm{Cs}}$ value for the strip is proportional to the concentration of nitrate in the aqueous phase; (4) the total cesium concentration of the waste feed is $0.00014 M$; (5) the temperature of the entire contactor cascade is $25^{\circ} \mathrm{C}$; (6) the stage efficiency is $80 \%$; (7) $0.1 \%$ other-phase carryover occurs between stages; (8) there are 15 extraction stages, 2 scrub stages, and 15 strip stages; (9) there are $20.1 \mathrm{gal} / \mathrm{min}$ of waste feed and $1.33 \mathrm{gal} / \mathrm{min}$ of strip feed; and (10) the O:A in the scrub section is 5.0.

The results of the calculations are given in Table 8 . The robustness number $(\mathrm{Rb})$ is defined as the ratio of the decontamination factor for a given set of flow sheet conditions to the process-required bounding decontamination factor of 40,000. The baseline flow sheet specifies a solvent flow rate of $6.6 \mathrm{gal} / \mathrm{min} .{ }^{1}$ The maximum robustness was obtained by varying the solvent flow rate, which is shown in the fourth column of Table 8.

All of the solvent compositions tested meet the bounding criterion for robustness at the baseline solvent flow rate; however, the two solvent compositions containing $10 \mathrm{~m} M$ TOA do not meet the "goal" (i.e., the target criterion) for robustness. When the solvent flow rate is adjusted to achieve the maximum robustness, all of the solvent compositions meet the goal for robustness.

It should be noted that the SASSE calculations are conservative since they assume a constant process temperature and a stage efficiency of $80 \%$. In the actual process, the extraction section will be kept cooler than the strip section, thereby improving the process robustness. For example, if the extraction section were at $25^{\circ} \mathrm{C}$, the scrub section at $29^{\circ} \mathrm{C}$, and the strip section at $33^{\circ} \mathrm{C}$, the robustness for the baseline solvent at a flow rate of $6.6 \mathrm{gal} / \mathrm{min}$ increases from 21.9 to 80.7. Thus, process robustness can be increased substantially by means of temperature control.

While a stage efficiency of $80 \%$ was assumed for the centrifugal contactor, the expected efficiency will be greater than $90 \% .^{18,19}$ Assuming a $90 \%$ stage efficiency in the SASSE calculations at $25^{\circ} \mathrm{C}$, the robustness for the baseline solvent at a flow rate of $6.6 \mathrm{gal} / \mathrm{min}$ would increase from 21.9 to 599 . Thus, higher stage efficiency, which we can expect with the plant-scale contactors, will also increase process robustness. 
Table 8. Calculated robustness for various CSSX solvent compositions

\begin{tabular}{lccc}
\hline Solvent identification $^{a}$ & $\begin{array}{c}\text { Rb at } 6.6 \text { gal/min } \\
\text { waste feed }\end{array}$ & $\mathrm{Rb}_{\max }$ & $\begin{array}{c}\text { Optimum flow rate } \\
\text { (Flow rate at } \mathrm{Rb}_{\text {max }}, \text { gal/min) }\end{array}$ \\
\hline Current baseline & 21.9 & 25.3 & 6.1 \\
B001107-3-1 & 11.9 & 26.4 & 5.3 \\
B001107-3-2 & 25.0 & 25.3 & 6.7 \\
B001107-3-3 & 6.6 & 23.6 & 4.9 \\
B001107-3-4 & 19.3 & 20.7 & 6.2 \\
B001107-3-5 & 8.8 & 24.3 & 8.5 \\
B001107-3-6 & 15.7 & 21.2 & 5.8 \\
B001107-3-7 & 9.1 & 17.8 & 8.0 \\
B001107-3-8 & 7.3 & 15.4 & 5.4 \\
B001107-3-9 & 14.3 & 15.6 & 7.0 \\
B001107-3-2A & 8.8 & 10.1 & 6.1 \\
B001107-3-2B & 1.1 & 3.0 & 5.3 \\
B001107-3-4C & 6.9 & 9.7 & 5.3 \\
B001107-3-4D & 1.0 & 3.2 & 5.3 \\
\hline
\end{tabular}

${ }^{a}$ See Table 2 for the composition of the specified solvent.

\subsection{THIRD-PHASE FORMATION}

One of the major criteria the solvent must meet is the absence of third-phase formation for the expected maximum loading of the solvent at $15^{\circ} \mathrm{C}$, which occurs at the high cesium and potassium concentrations. This requirement was determined in FY 2001 at the time the process temperature range was established. ${ }^{1}$ The results of the third-phase evaluations for solvents containing $1 \mathrm{~m} M$ TOA are presented in Table 9. Results of these experiments indicate that the use of any solvent containing $10 \mathrm{~m} M$ BOBCalixC6 is not recommended at a Cs-7SB modifier concentration less than $0.75 \mathrm{M}$. 
Table 9. Temperature range for third-phase appearance

\begin{tabular}{ccccc}
\hline & & \multicolumn{3}{c}{ Temperature range $\left({ }^{\circ} \mathrm{C}\right)$} \\
\cline { 3 - 5 } BOBCalixC6 $(\mathrm{m} M)$ & Cs-7SB $(M)$ & $\begin{array}{c}\text { Full SRS } \\
\text { simulant }\end{array}$ & $\begin{array}{c}\text { High-potassium } \\
\text { simulant }\end{array}$ & $\begin{array}{c}\text { High-cesium and high- } \\
\text { potassium simulant }\end{array}$ \\
\hline 10 & 0.50 & $15.0-16.5$ & $17.5-20.0$ & $17.5-20.0$ \\
10 & 0.65 & $12.0-13.0$ & $15.0-16.5$ & $15.0-16.5$ \\
10 & 0.75 & $10.0-11.0$ & $12.0-13.0$ & $12.0-13.0$ \\
8 & 0.65 & $10.0-11.0$ & $12.0-13.0$ & $12.0-13.0$ \\
8 & 0.75 & $8.5-9.0$ & $10.0-11.0$ & $10.0-11.0$ \\
8 & 0.85 & $7.5-8.0$ & $8.5-9.0$ & $8.5-9.0$ \\
6 & 1.0 & $6.5-7.0$ & $6.5-7.0$ & $6.5-7.0$ \\
6 & 0.75 & $6.5-7.0$ & $8.0-8.5$ & $8.5-9.0$ \\
6 & 0.85 & $5.0-6.5$ & $7.0-7.5$ & $7.0-7.5$ \\
\hline
\end{tabular}

${ }^{a}$ The letter "F" indicates that the solvent did not exhibit a third phase at $5^{\circ} \mathrm{C}$. However, because of the high concentration of modifier, the solvent viscosity had increased significantly at that temperature, making observation of a third phase difficult.

\subsection{SOLVENT DISPERSION NUMBERS}

The results for the dispersion-number determinations are given in Table 10 and shown graphically in Fig. 2. The subset of the solvent test samples contained $1 \mathrm{~m} M$ TOA. The data for the baseline solvent are taken from earlier testing. ${ }^{18}$ The results show that all nine compositions meet the dispersion number criterion for extraction, scrub, and strip conditions.

Dispersion-number determinations for a selected subset of the samples against $10 \mathrm{~m} M \mathrm{NaOH}$ wash solutions are shown in Fig. 3. None of the solvent samples met the $\mathrm{NaOH}$ solvent-wash solution criterion. The $10 \mathrm{~m} M \mathrm{NaOH}$ concentration was used during the FY 2001 flow sheet tests at Argonne National Laboratory, ${ }^{20}$ which used simulant as the feed, and tests at Savannah River Technology Center, ${ }^{21}$ which used real waste as the feed. During these tests, small amounts of emulsion formation were observed. Solvent samples B001107-3-4 and B001107-3-5 were determined to have the most-desirable 
Table 10. Dispersion numbers for extraction, scrub, and stripping of CSSX solvents

\begin{tabular}{ccccc}
\hline & \multicolumn{4}{c}{ Dispersion number } \\
\cline { 2 - 5 } $\begin{array}{c}\text { Sample } \\
\text { description }^{a}\end{array}$ & Simulant/solvent & Scrub/solvent & Strip/solvent & $\begin{array}{c}\text { Wash/solvent } \\
0.01 ~ N \text { NaOH } \\
(\text { O:A }=5: 1)\end{array}$ \\
\hline Original solvent $^{b}$ & 0.00149 & 0.000964 & 0.00115 & - \\
B001107-3-1 & 0.000750 & 0.001019 & 0.000909 & - \\
B001107-3-2 & 0.000565 & 0.000700 & 0.000776 & 0.000221 \\
B001107-3-3 & 0.001021 & 0.000522 & 0.000886 & - \\
B001107-3-4 & 0.001025 & 0.000530 & 0.000941 & 0.000345 \\
B001107-3-5 & 0.001181 & 0.000501 & 0.000876 & 0.000238 \\
B001107-3-6 & 0.001051 & 0.000589 & 0.000751 & 0.000163 \\
B001107-3-7 & 0.001252 & 0.000581 & 0.000846 & 0.000159 \\
B001107-3-8 & 0.001201 & 0.000622 & 0.000541 & - \\
B001107-3-9 & 0.001411 & 0.000408 & 0.000506 & - \\
\hline
\end{tabular}

${ }^{a}$ See Table 2 for the composition of the specified solvent.

${ }^{b}$ Original solvent data were taken on the baseline virgin solvent.

characteristics when compared against all of the selection criteria. These two solvents were selected for dispersion-number determinations as a function of $\mathrm{NaOH}$ concentrations. The results of these tests are given in Table 11 and shown graphically in Fig. 4. When the $\mathrm{NaOH}$ concentration was $300 \mathrm{~m} M$, these two solvent compositions met the dispersion-number criterion for solvent washing.

\subsection{SOLVENT DENSITY}

The results of the density determinations are presented in Table 12. As expected, solvent density is primarily dependent on the modifier concentration. The relationship between density and modifier concentration is shown in Fig. 5. All the solvent samples that were tested met the bounding criterion for density; however, the solvent samples with modifier concentrations equal to or greater than $0.85 M$ did not meet the goal for density. 


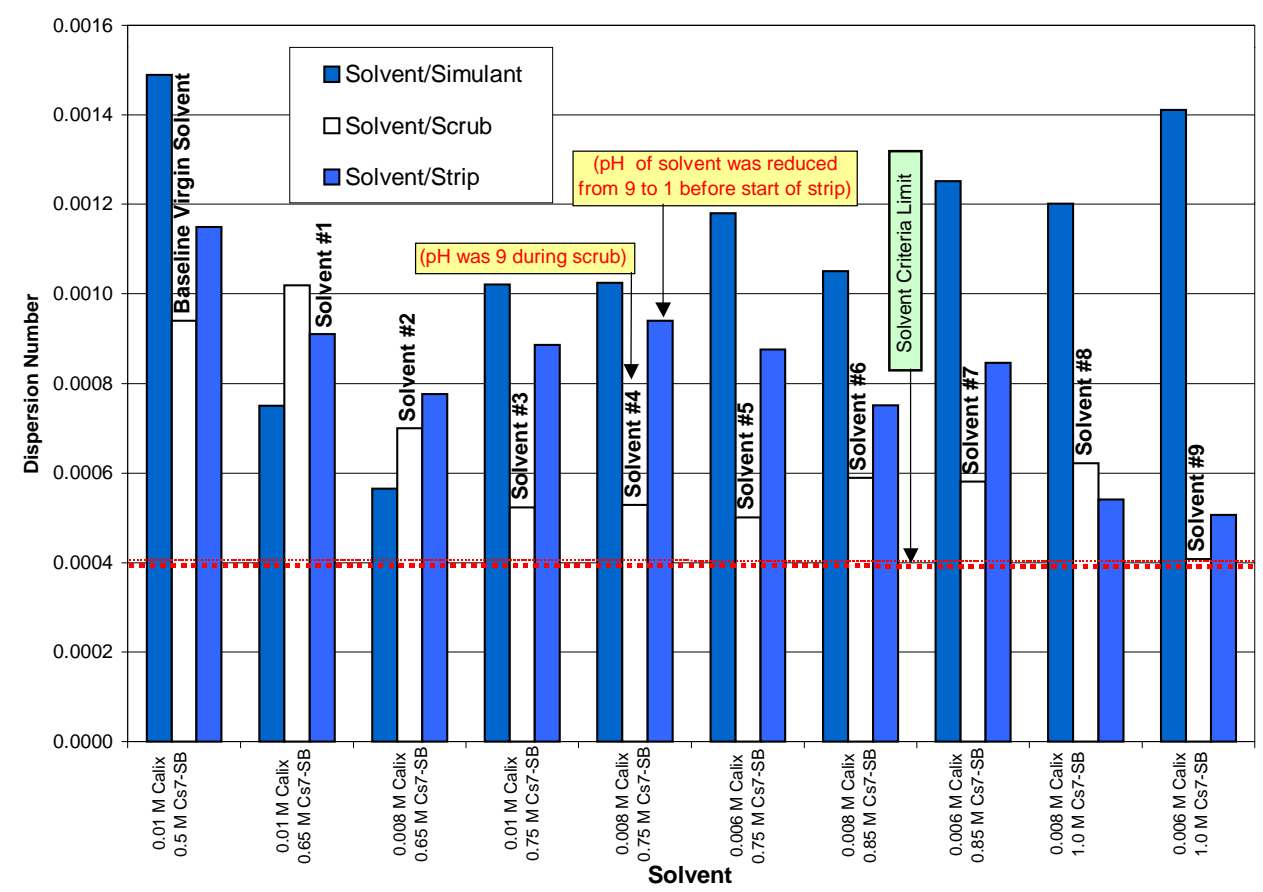

Fig. 2. CSSX solvent dispersion numbers for extraction, scrub, and strip conditions at baseline $\mathrm{O}$ :A ratios.

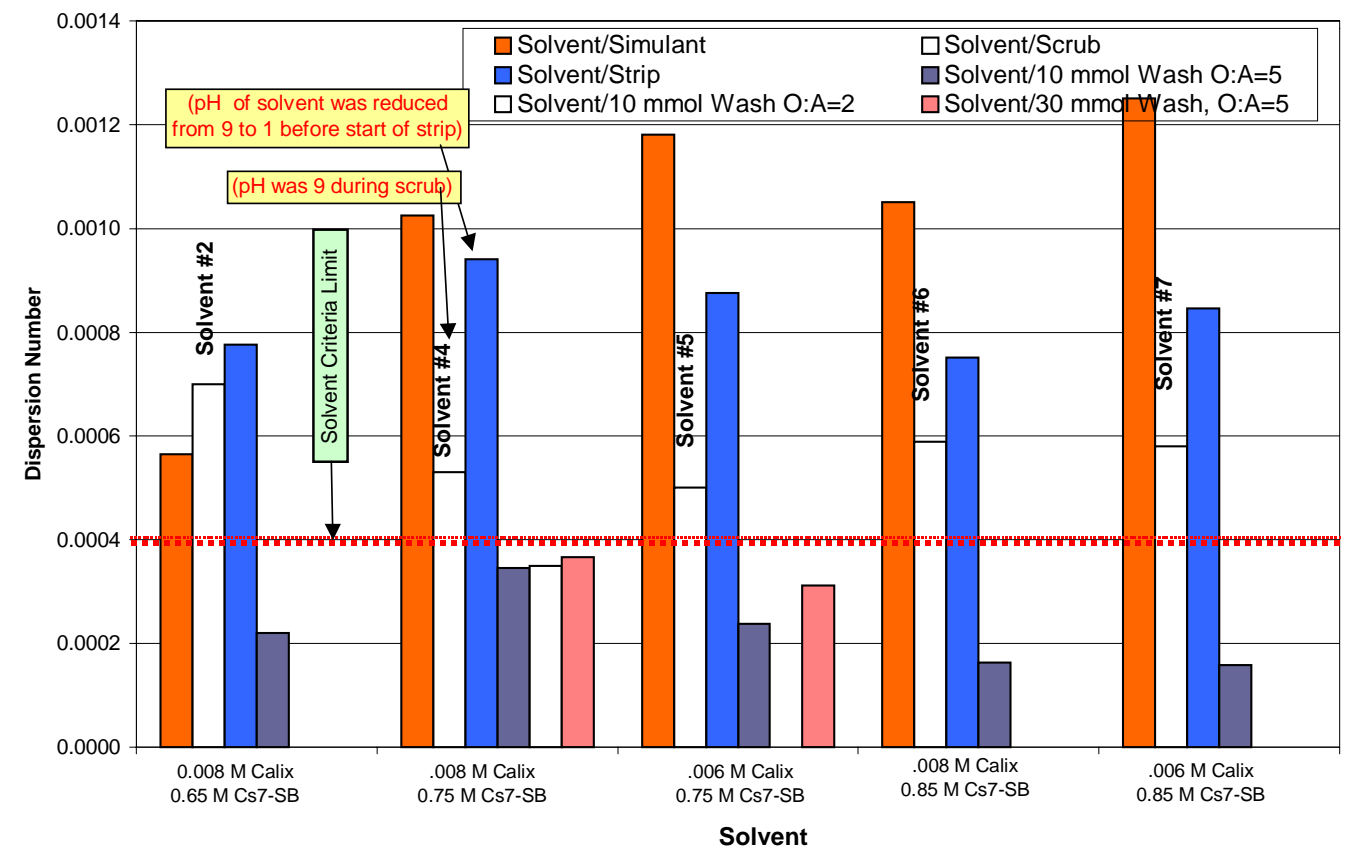

Fig. 3. CSSX solvent dispersion numbers for solvent wash with dilute $\mathrm{NaOH}$. 
Table 11. Dispersion numbers for washing of CSSX solvents B001107-3-4 and B001107-3-5

\begin{tabular}{lllll}
\hline & \multicolumn{4}{c}{ Solvent/wash dispersion number } \\
\cline { 2 - 5 } $\begin{array}{c}\text { Solvent } \\
\text { description }^{a}\end{array}$ & $0.01 \mathrm{M} \mathrm{NaOH}$ wash & $0.03 \mathrm{M} \mathrm{NaOH}$ wash & $0.1 \mathrm{M} \mathrm{NaOH}$ wash & $0.3 \mathrm{M} \mathrm{NaOH}$ wash \\
\hline B001107-3-4 & 0.000345 & 0.000366 & 0.000368 & 0.000490 \\
B001107-3-5 & 0.000238 & 0.000311 & 0.000241 & 0.000450 \\
\hline
\end{tabular}

${ }^{a}$ See Table 2 for the composition of the specified solvent.

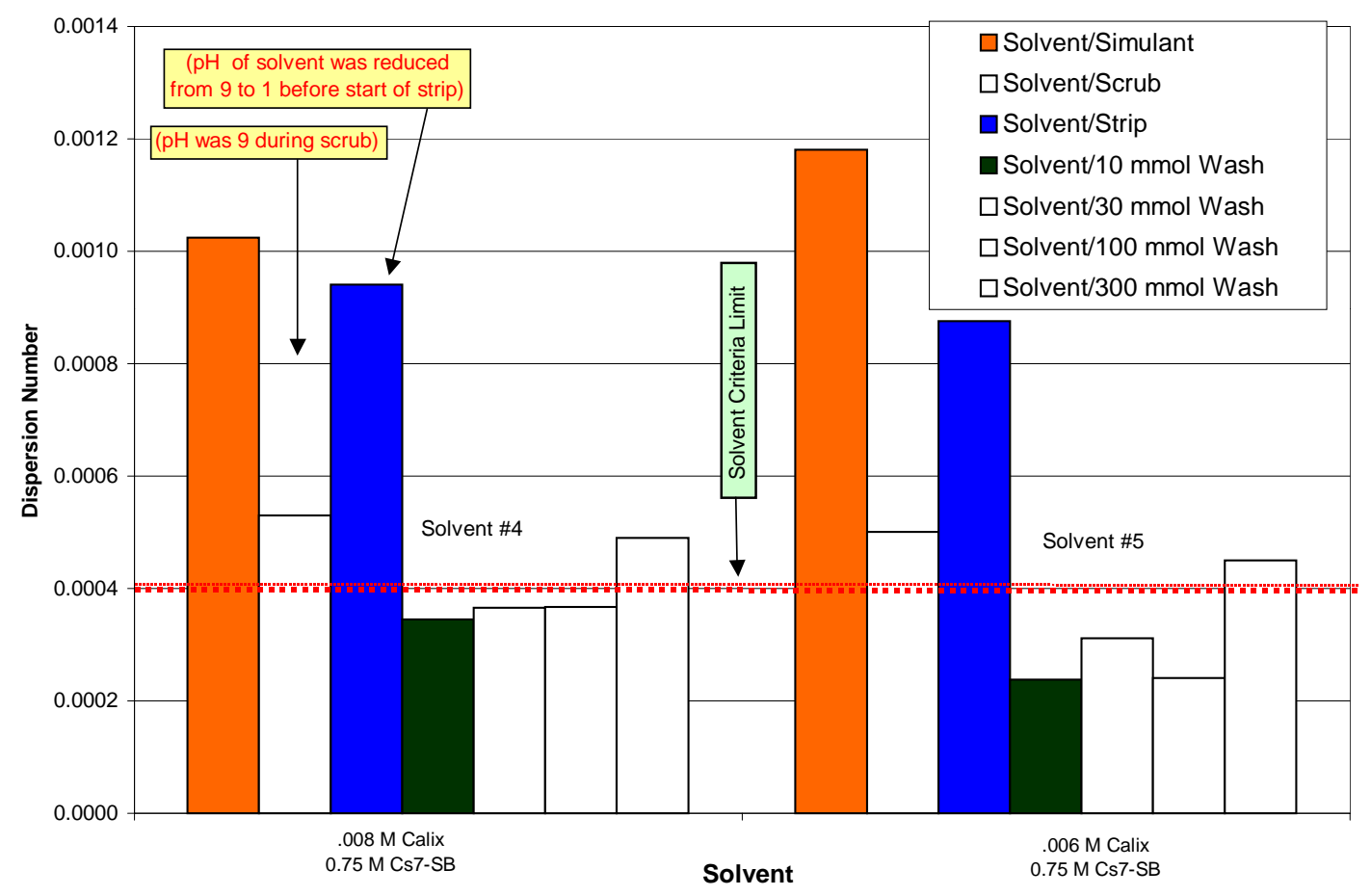

Fig. 4. CSSX solvent dispersion numbers for solvent wash conditions as a function of $\mathrm{NaOH}$ concentration.

\subsection{SOLVENT VISCOSITY}

The results of the solvent viscosity measurements are shown in Fig. 6, and Fig. 7 shows the shear stress as a function of temperature. The data are presented in tabular form in Table 13. 
Table 12. Solvent density determinations

\begin{tabular}{ccccccccc}
\hline $\begin{array}{c}\text { Solvent } \\
\text { identification }^{a}\end{array}$ & $\begin{array}{c}\text { Mass of } \\
\text { solvent } \\
(\mathrm{g})\end{array}$ & $\begin{array}{c}\text { Density } \\
\left(\mathrm{g} / \mathrm{cm}^{3}\right)\end{array}$ & $\begin{array}{c}\text { Calix } \\
(M)\end{array}$ & $\begin{array}{c}\text { Modifier } \\
(M)\end{array}$ & $\begin{array}{c}\text { Corrected } \\
\text { volume } \\
(\mathrm{mL})\end{array}$ & $\begin{array}{c}\text { Mass of } \\
\text { water } \\
(\mathrm{g})\end{array}$ & $\begin{array}{c}\text { Sp gr } \\
\text { vol. }\end{array}$ & $\begin{array}{c}\text { flask } \\
\text { Baseline }\end{array}$ \\
\hline B001107-3-1 & 41.9085 & 0.8395 & 0.010 & 0.65 & 49.9202 & 49.7819 & 0.99723 & 1 \\
B001107-3-2 & 41.9230 & 0.8395 & 0.008 & 0.65 & 49.9362 & 49.7979 & 0.99723 & 2 \\
B001107-3-3 & 42.5920 & 0.8531 & 0.010 & 0.75 & 49.9242 & 49.7859 & 0.99723 & 3 \\
B001107-3-4 & 42.5149 & 0.8525 & 0.008 & 0.75 & 49.8703 & 49.7322 & 0.99723 & 5 \\
B001107-3-5 & 42.4714 & 0.8516 & 0.006 & 0.75 & 49.8703 & 49.7322 & 0.99723 & 5 \\
B001107-3-6 & 43.0887 & 0.8644 & 0.008 & 0.85 & 49.8480 & 49.7099 & 0.99723 & 6 \\
B001107-3-7 & 43.1036 & 0.8632 & 0.006 & 0.85 & 49.9362 & 49.7979 & 0.99723 & 2 \\
B001107-3-8 & 44.0269 & 0.8819 & 0.008 & 1.00 & 49.9242 & 49.7859 & 0.99723 & 3 \\
B001107-3-9 & 44.6565 & 0.8951 & 0.006 & 1.00 & 49.8925 & 49.7543 & 0.99723 & 4 \\
\hline
\end{tabular}

${ }^{a}$ See Table 2 for the composition of the specified solvent.

${ }^{b}$ Temperature $=25.6^{\circ} \mathrm{C}$.

${ }^{c}$ Measured previously on baseline virgin solvent.

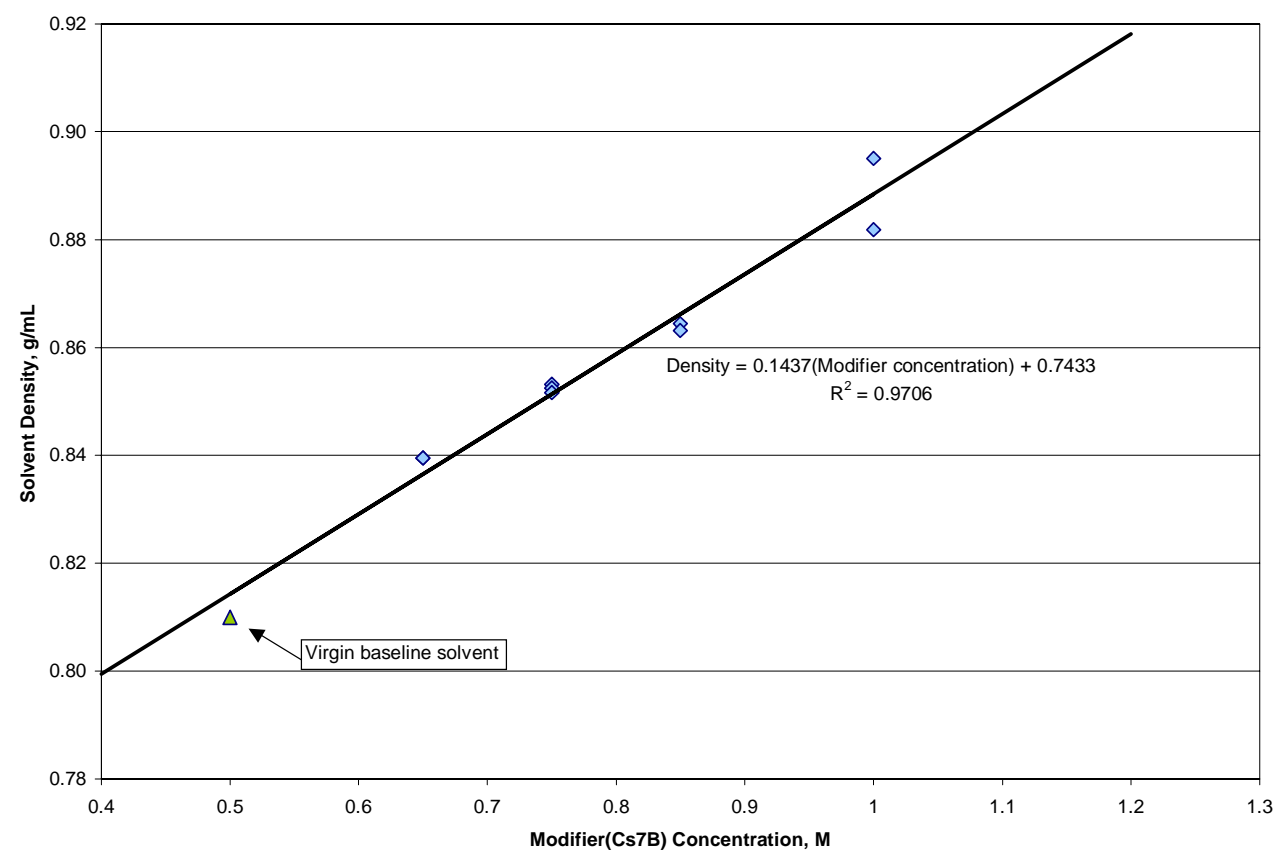

Fig. 5. CSSX solvent density as a function of Cs-7SB modifier concentration for $25.6^{\circ} \mathrm{C}$. 


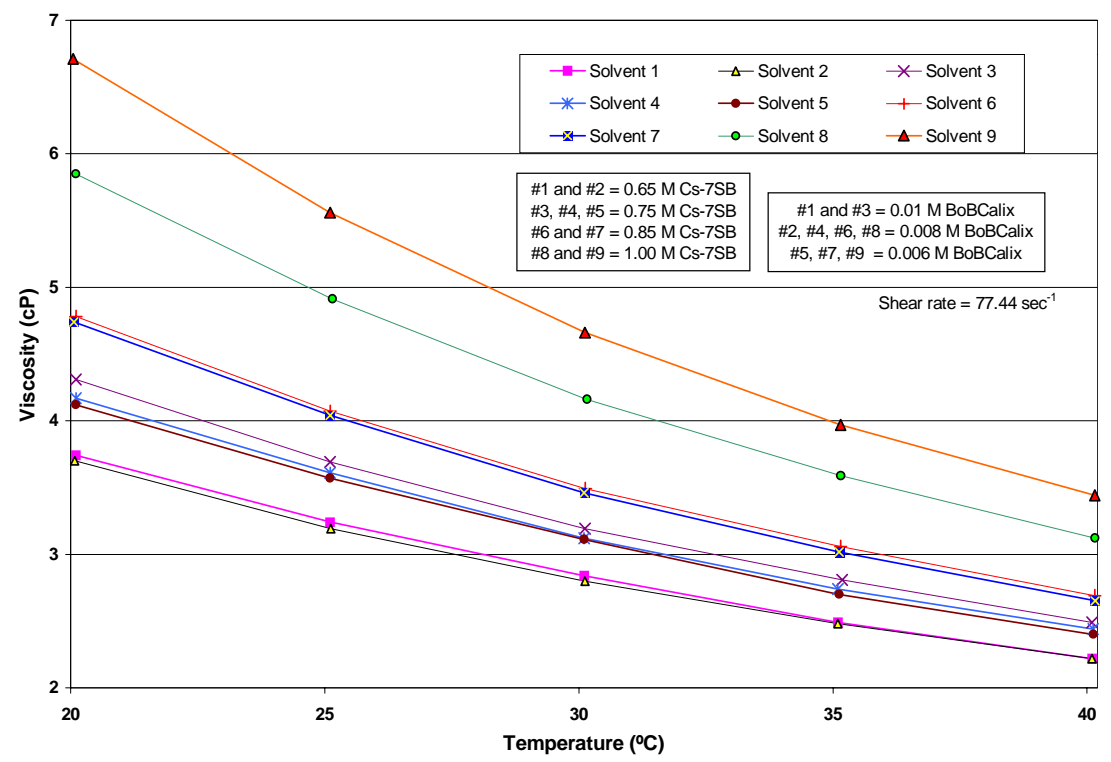

Fig. 6. Solvent viscosity as a function of temperature. The numbers in the legend are the test numbers from Table 2.

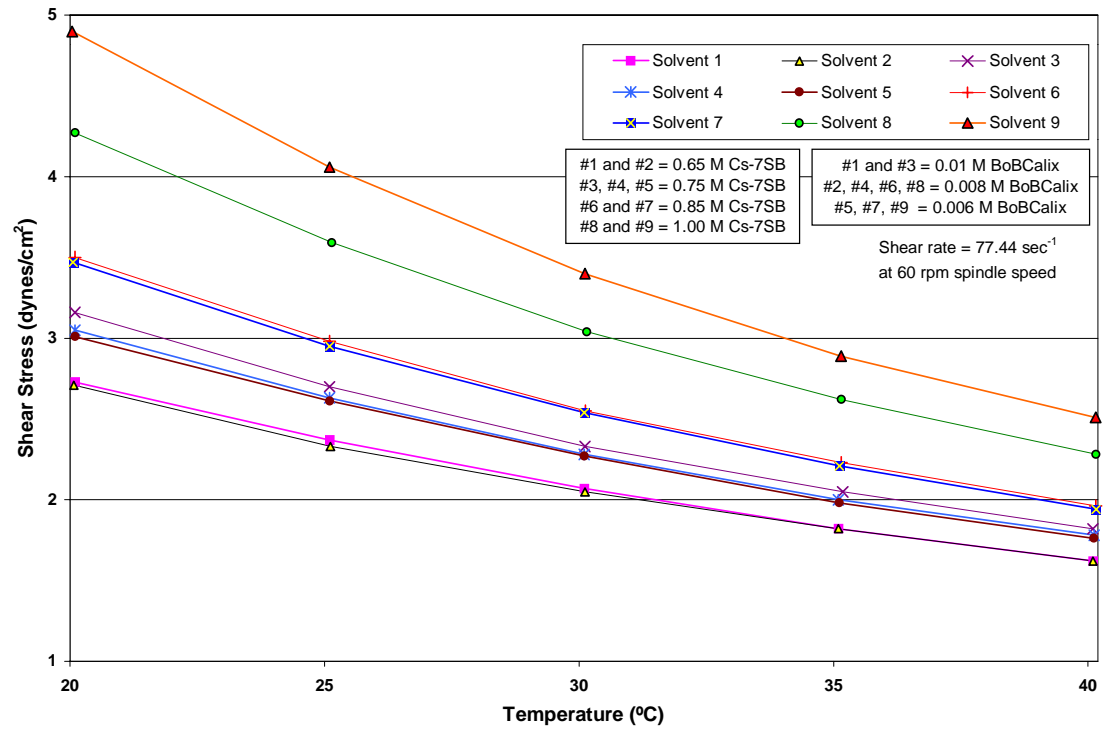

Fig. 7. Solvent shear stress as a function of temperature. The solvent numbers in the legend are the test numbers from Table 2.

The solvents with the lowest concentrations of the Cs-7SB modifier have the lowest viscosity. The BOBCalixC6 concentration has only a minor effect on the viscosity decrease, because its concentration decreases at a given Cs-7SB concentration. The viscosity of all solvent samples decreases with increasing temperature, as expected for this type of liquid. 
Table 13. Solvent viscosity determinations ${ }^{a}$

\begin{tabular}{|c|c|c|c|c|}
\hline Solvent ${ }^{b}$ & $\begin{array}{c}\text { Temperature } \\
\left({ }^{\circ} \mathrm{C}\right)\end{array}$ & $\begin{array}{l}\text { Torque } \\
(\%)\end{array}$ & $\begin{array}{l}\text { Viscosity } \\
(\mathrm{cP})^{c}\end{array}$ & $\begin{array}{c}\text { Shear stress } \\
\left(\mathrm{dyn} / \mathrm{cm}^{2}\right)\end{array}$ \\
\hline В001107-3-1 & $\begin{array}{l}20.00 \\
25.00 \\
30.00 \\
35.00 \\
40.00\end{array}$ & $\begin{array}{l}37.3 \\
32.3 \\
28.2 \\
24.9 \\
22.2\end{array}$ & $\begin{array}{l}3.74 \\
3.24 \\
2.84 \\
2.49 \\
2.22\end{array}$ & $\begin{array}{l}2.73 \\
2.37 \\
2.07 \\
1.82 \\
1.62\end{array}$ \\
\hline B001107-3-2 & $\begin{array}{l}19.98 \\
25.02 \\
30.02 \\
35.00 \\
40.00\end{array}$ & $\begin{array}{l}36.9 \\
31.9 \\
28.0 \\
24.8 \\
22.2\end{array}$ & $\begin{array}{l}3.70 \\
3.19 \\
2.80 \\
2.48 \\
2.22\end{array}$ & $\begin{array}{l}2.71 \\
2.33 \\
2.05 \\
1.82 \\
1.62\end{array}$ \\
\hline B001107-3-3 & $\begin{array}{l}20.00 \\
25.00 \\
30.02 \\
35.08 \\
40.00\end{array}$ & $\begin{array}{l}43.2 \\
36.9 \\
31.9 \\
28.0 \\
24.8\end{array}$ & $\begin{array}{l}4.31 \\
3.69 \\
3.19 \\
2.81 \\
2.49\end{array}$ & $\begin{array}{l}3.16 \\
2.70 \\
2.33 \\
2.05 \\
1.82\end{array}$ \\
\hline B001107-3-4 & $\begin{array}{l}20.00 \\
25.00 \\
30.00 \\
35.00 \\
40.02\end{array}$ & $\begin{array}{l}41.8 \\
36.0 \\
31.2 \\
27.4 \\
24.4\end{array}$ & $\begin{array}{l}4.17 \\
3.61 \\
3.12 \\
2.74 \\
2.44\end{array}$ & $\begin{array}{l}3.05 \\
2.63 \\
2.28 \\
2.00 \\
1.78\end{array}$ \\
\hline B001107-3-5 & $\begin{array}{l}20.00 \\
25.00 \\
30.00 \\
35.02 \\
40.02\end{array}$ & $\begin{array}{l}41.3 \\
35.7 \\
31.0 \\
27.1 \\
24.0\end{array}$ & $\begin{array}{l}4.12 \\
3.57 \\
3.11 \\
2.70 \\
2.40\end{array}$ & $\begin{array}{l}3.01 \\
2.61 \\
2.27 \\
1.98 \\
1.76\end{array}$ \\
\hline В001107-3-6 & $\begin{array}{l}20.00 \\
25.00 \\
30.03 \\
35.05 \\
40.05\end{array}$ & $\begin{array}{l}47.8 \\
40.7 \\
34.9 \\
30.5 \\
26.8\end{array}$ & $\begin{array}{l}4.78 \\
4.07 \\
3.49 \\
3.06 \\
2.69\end{array}$ & $\begin{array}{l}3.50 \\
2.98 \\
2.55 \\
2.23 \\
1.96\end{array}$ \\
\hline B001107-3-7 & $\begin{array}{l}19.96 \\
25.00 \\
30.00 \\
35.02 \\
40.06\end{array}$ & $\begin{array}{l}47.3 \\
40.3 \\
34.6 \\
30.2 \\
26.6\end{array}$ & $\begin{array}{l}4.74 \\
4.04 \\
3.46 \\
3.02 \\
2.65\end{array}$ & $\begin{array}{l}3.47 \\
2.95 \\
2.54 \\
2.21 \\
1.94\end{array}$ \\
\hline B001107-3-8 & $\begin{array}{l}20.00 \\
25.05 \\
30.06 \\
35.06 \\
40.06\end{array}$ & $\begin{array}{l}58.5 \\
49.0 \\
41.6 \\
35.8 \\
31.3\end{array}$ & $\begin{array}{l}5.85 \\
4.91 \\
4.16 \\
3.59 \\
3.12\end{array}$ & $\begin{array}{l}4.27 \\
3.59 \\
3.04 \\
2.62 \\
2.28\end{array}$ \\
\hline В001107-3-9 & $\begin{array}{l}19.95 \\
25.00 \\
30.02 \\
35.05 \\
40.05\end{array}$ & $\begin{array}{l}67.1 \\
55.4 \\
46.5 \\
39.7 \\
34.3\end{array}$ & $\begin{array}{l}6.71 \\
5.56 \\
4.66 \\
3.97 \\
3.44\end{array}$ & $\begin{array}{l}4.90 \\
4.06 \\
3.40 \\
2.89 \\
2.51\end{array}$ \\
\hline
\end{tabular}

${ }^{a}$ Brookfield LVTDV-II (serial number D15869) UL adapter with heating jacket.

${ }^{b}$ See Table 2 for the composition of the specified solvent.

${ }^{c} \mathrm{SD}= \pm 0.1$ centipoise $(\mathrm{cP})$. 


\subsection{SOLVENT INTERFACIAL TENSION}

The results of the measurements are given in Tables 14-17 and are shown graphically in Figs. 8 and 9. The tables contain the data for the four series of tests. Figure 8 shows the surface tension of the solvents and also contains the surface tensions of the simulant, scrub solution, and strip solutions. Figure 9 shows the interfacial tension of the solvents versus simulant, scrub, and strip solutions. The results reveal nothing unusual, and the individual solvents behave similarly with the three aqueous solutions tested.

Table 14. Surface tension determinations

\begin{tabular}{|c|c|c|c|c|c|c|}
\hline \multirow{2}{*}{$\begin{array}{c}\text { Solvent } \\
\text { identification }^{a}\end{array}$} & \multirow{2}{*}{$\begin{array}{l}\text { Density, D } \\
\left(\mathrm{g} / \mathrm{cm}^{3}\right)\end{array}$} & \multicolumn{2}{|c|}{$\begin{array}{l}\text { Indicated } \\
\text { surface tension } \\
\quad(\text { dyn } / \mathrm{cm})\end{array}$} & \multirow{2}{*}{$\begin{array}{l}\text { Instrument } \\
\text { reading, } \\
\text { average } \\
\text { (P) }\end{array}$} & \multirow{2}{*}{$\begin{array}{l}\text { Correction } \\
\text { factor } \\
\text { from formula }\end{array}$} & \multirow{2}{*}{$\begin{array}{c}\text { Actual } \\
\text { surface } \\
\text { tension } \\
(\text { dyn } / \mathrm{cm})\end{array}$} \\
\hline & & Trial 1 & Trial 2 & & & \\
\hline B001107-3-1 & 0.8395 & 26.9 & 26.8 & 26.9 & 0.8896 & 23.9 \\
\hline B001107-3-2 & 0.8395 & 26.8 & 26.8 & 26.8 & 0.8895 & 23.8 \\
\hline B001107-3-3 & 0.8531 & 26.8 & 26.7 & 26.8 & 0.8888 & 23.8 \\
\hline B001107-3-4 & 0.8525 & 26.8 & 26.9 & 26.9 & 0.8890 & 23.9 \\
\hline B001107-3-5 & 0.8516 & 27.0 & 27.1 & 27.1 & 0.8893 & 24.1 \\
\hline B001107-3-6 & 0.8644 & 27.0 & 26.9 & 27.0 & 0.8886 & 23.9 \\
\hline B001107-3-7 & 0.8632 & 26.9 & 27.0 & 27.0 & 0.8886 & 23.9 \\
\hline B001107-3-8 & 0.8819 & 27.0 & 27.1 & 27.1 & 0.8879 & 24.0 \\
\hline B001107-3-9 & 0.8951 & 27.1 & 27.0 & 27.1 & 0.8874 & 24.0 \\
\hline Strip & 0.9974 & 41.0 & 40.0 & 40.5 & 0.8999 & 36.4 \\
\hline Scrub & 0.9984 & 48.3 & 48.1 & 48.2 & 0.9085 & 43.8 \\
\hline Simulant & 1.2536 & 64.6 & 64.8 & 64.7 & 0.9122 & 59.0 \\
\hline
\end{tabular}

${ }^{a}$ See Table 2 for the composition of the specified solvent. 
Table 15. Interfacial tension versus simulant

\begin{tabular}{|c|c|c|c|c|c|c|}
\hline \multirow{2}{*}{$\begin{array}{c}\text { Solvent } \\
\text { identification }\end{array}$} & \multirow{2}{*}{$\begin{array}{l}\text { Density } \\
\left(\mathrm{g} / \mathrm{cm}^{3}\right)\end{array}$} & \multicolumn{2}{|c|}{$\begin{array}{c}\text { Indicated } \\
\text { interfacial tension } \\
(\mathrm{dyn} / \mathrm{cm})\end{array}$} & \multirow{2}{*}{$\begin{array}{l}\text { Instrument } \\
\text { reading, } \\
\text { average } \\
(\mathrm{P})\end{array}$} & \multirow{2}{*}{$\begin{array}{l}\text { Correction } \\
\text { factor } \\
\text { from formula }\end{array}$} & \multirow{2}{*}{$\begin{array}{c}\text { Actual } \\
\text { interfacial } \\
\text { tension } \\
(\mathrm{dyn} / \mathrm{cm})\end{array}$} \\
\hline & & Trial 1 & Trial 2 & & & \\
\hline В001107-3-1 & 0.8395 & 20.5 & 20.8 & 20.7 & 0.9103 & 18.8 \\
\hline B001107-3-2 & 0.8395 & 20.8 & 20.7 & 20.8 & 0.9106 & 18.9 \\
\hline В001107-3-3 & 0.8531 & 20.9 & 20.8 & 20.9 & 0.9127 & 19.0 \\
\hline B001107-3-4 & 0.8525 & 20.7 & 20.5 & 20.6 & 0.9119 & 18.8 \\
\hline B001107-3-5 & 0.8516 & 20.7 & 20.6 & 20.7 & 0.9119 & 18.8 \\
\hline В001107-3-6 & 0.8644 & 20.3 & 20.4 & 20.4 & 0.9129 & 18.6 \\
\hline В001107-3-7 & 0.8632 & 20.2 & 20.4 & 20.3 & 0.9126 & 18.5 \\
\hline В001107-3-8 & 0.8819 & 20.5 & 20.5 & 20.5 & 0.9160 & 18.8 \\
\hline В001107-3-9 & 0.8951 & 20.1 & 20.3 & 20.2 & 0.9172 & 18.5 \\
\hline
\end{tabular}

${ }^{a}$ See Table 2 for the composition of the specified solvent.

Table 16. Interfacial tension versus scrub solution

\begin{tabular}{|c|c|c|c|c|c|c|}
\hline \multirow{2}{*}{$\begin{array}{c}\text { Solvent } \\
\text { identification }\end{array}$} & \multirow{2}{*}{$\begin{array}{l}\text { Density } \\
\left(\mathrm{g} / \mathrm{cm}^{3}\right)\end{array}$} & \multicolumn{2}{|c|}{$\begin{array}{c}\text { Indicated } \\
\text { interfacial tension } \\
(\mathrm{dyn} / \mathrm{cm})\end{array}$} & \multirow{2}{*}{$\begin{array}{l}\text { Instrument } \\
\text { reading, } \\
\text { average } \\
\text { (P) }\end{array}$} & \multirow{2}{*}{$\begin{array}{l}\text { Correction } \\
\text { factor } \\
\text { from formula }\end{array}$} & \multirow{2}{*}{$\begin{array}{c}\text { Actual } \\
\text { interfacia } \\
\text { tension } \\
(\mathrm{dyn} / \mathrm{cm})\end{array}$} \\
\hline & & Trial 1 & Trial 2 & & & \\
\hline B001107-3-1 & 0.8395 & 18.6 & 17.5 & 18.1 & 0.9703 & 17.5 \\
\hline В001107-3-2 & 0.8395 & 16.8 & 16.9 & 16.9 & 0.9640 & 16.2 \\
\hline B001107-3-3 & 0.8531 & 16.5 & 16.6 & 16.6 & 0.9706 & 16.1 \\
\hline B001107-3-4 & 0.8525 & 16.7 & 16.5 & 16.6 & 0.9704 & 16.1 \\
\hline В001107-3-5 & 0.8516 & 16.6 & 16.5 & 16.6 & 0.9696 & 16.0 \\
\hline B001107-3-6 & 0.8644 & 16.4 & 16.3 & 16.4 & 0.9772 & 16.0 \\
\hline В001107-3-7 & 0.8632 & 16.1 & 16.1 & 16.1 & 0.9748 & 15.7 \\
\hline В001107-3-8 & 0.8819 & 16.0 & 16.0 & 16.0 & 0.9892 & 15.8 \\
\hline B001107-3-9 & 0.8951 & 16.0 & 15.8 & 15.9 & 1.0016 & 15.9 \\
\hline
\end{tabular}

${ }^{a}$ See Table 2 for the composition of the specified solvent. 
Table 17. Interfacial tension versus strip solution

\begin{tabular}{|c|c|c|c|c|c|c|}
\hline \multirow{2}{*}{$\begin{array}{c}\text { Solvent } \\
\text { identification }^{a}\end{array}$} & \multirow{2}{*}{$\begin{array}{l}\text { Density } \\
\left(\mathrm{g} / \mathrm{cm}^{3}\right)\end{array}$} & \multicolumn{2}{|c|}{$\begin{array}{c}\text { Indicated } \\
\text { interfacial tension } \\
(\mathrm{dyn} / \mathrm{cm})\end{array}$} & \multirow{2}{*}{$\begin{array}{l}\text { Instrument } \\
\text { reading, } \\
\text { average } \\
(\mathrm{P})\end{array}$} & \multirow{2}{*}{$\begin{array}{l}\text { Correction } \\
\text { factor } \\
\text { from formula }\end{array}$} & \multirow{2}{*}{$\begin{array}{c}\text { Actual } \\
\text { interfacial } \\
\text { tension } \\
(\mathrm{dyn} / \mathrm{cm})\end{array}$} \\
\hline & & Trial 1 & Trial 2 & & & \\
\hline B001107-3-1 & 0.8395 & 16.0 & 16.0 & 16.0 & 0.9599 & 15.4 \\
\hline B001107-3-2 & 0.8395 & 16.0 & 15.9 & 16.0 & 0.9596 & 15.3 \\
\hline B001107-3-3 & 0.8531 & 15.2 & 15.8 & 15.5 & 0.9651 & 15.0 \\
\hline B001107-3-4 & 0.8525 & 16.0 & 15.8 & 15.9 & 0.9670 & 15.4 \\
\hline B001107-3-5 & 0.8516 & 15.2 & 15.7 & 15.5 & 0.9639 & 14.9 \\
\hline B001107-3-6 & 0.8644 & 15.7 & 15.6 & 15.7 & 0.9736 & 15.2 \\
\hline B001107-3-7 & 0.8632 & 15.7 & 15.6 & 15.7 & 0.9727 & 15.2 \\
\hline B001107-3-8 & 0.8819 & 15.6 & 15.8 & 15.7 & 0.9880 & 15.5 \\
\hline B001107-3-9 & 0.8951 & 16.0 & 15.5 & 15.8 & 1.0015 & 15.8 \\
\hline
\end{tabular}

${ }^{a}$ See Table 2 for the composition of the specified solvent.

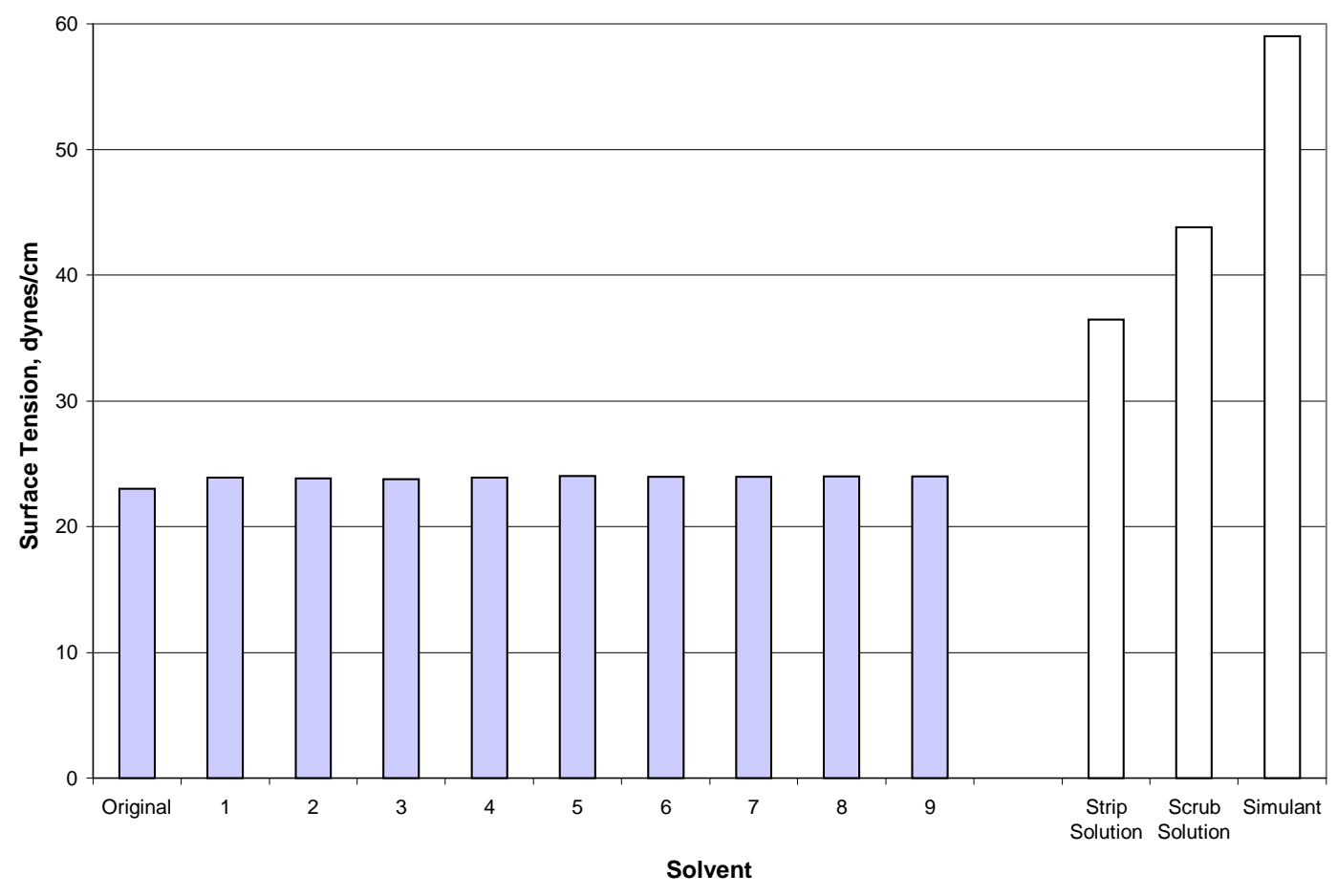

Fig. 8. Solvent and process solution surface tension. The numbers on the abscissa are the test numbers from Table 2 . 


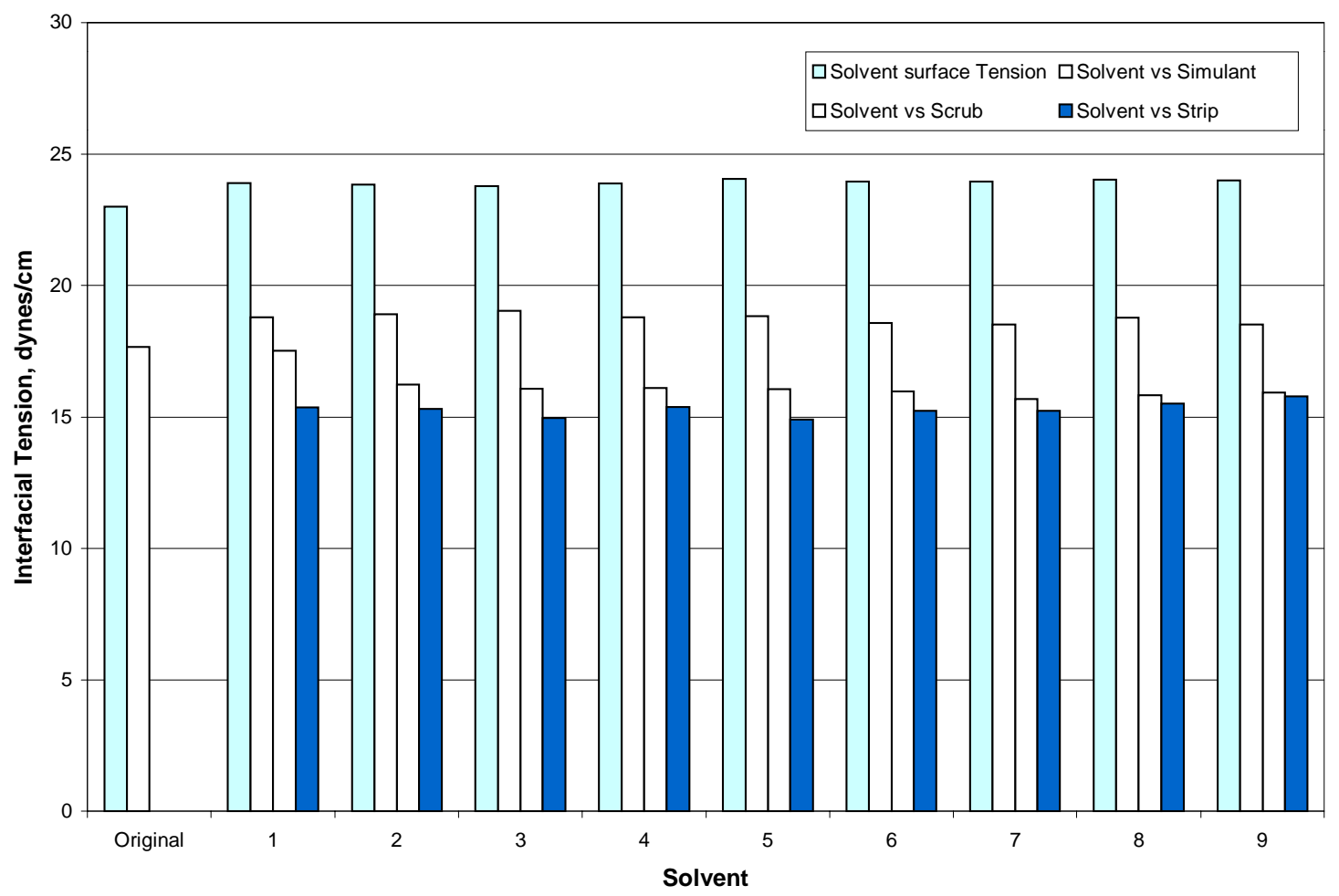

Fig. 9. Solvent interfacial tension in extraction, scrub, and strip contacts. The numbers on the abscissa are the test numbers from Table 2.

\section{SOLVENT COMPOSITION RECOMMENDATION PROCESS}

The process used by the CSSX team to arrive at the solvent-composition recommendation involved several actions. First, the experimental data described in this report were distributed to the team members. Second, two conference calls were held. During the first call, the methods of data acquisition and the significance of the data relative to the selection criteria were discussed. ${ }^{4}$ The action item from this discussion was for each participant to make a recommendation concerning the solvent composition and forward this information to all of the participants. A compilation of the individual recommendations was distributed prior to the second conference call. The second call focused on the individual recommendations. Between the two calls, a technical presentation was given during the weekly TFA program status review. ${ }^{22}$ The recommended composition was a consensus opinion of the CSSX technical team.

The rationale used by the CSSX team in arriving at the recommended solvent composition is described in Ref. 4. 
The primary criterion involved the selection of a composition that is thermodynamically stable with respect to the solubility of BOBCalixC6. The fact that BOBCalixC6 has a solubility limit of $7.55 \mathrm{~m} M$ suggests that the concentration should be less than $7.5 \mathrm{~m} M$ to accommodate variations in solvent preparation without exceeding this limit. The solubility data also indicate that the thermodynamic solubility value for BOBCalixC6 is linked to the Cs-7SB modifier concentration. For example, if the BOBCalxC6 concentration is $7 \mathrm{mM}$, the Cs-7SB modifier concentration should be approximately 100 times higher. The data on third-phase formation also suggest the need for a solvent composition with a BOBCalixC6 concentration of $8 \mathrm{~m} M$ or less and a Cs-7SB modifier concentration of at least $0.65 M$. The density criterion suggests compositions with the Cs-7SB modifier concentration equal to or less than $0.85 M$. Contactor throughput and phase separation are dependent on the density difference of the two phases; that is, for a given contactor size, throughput is higher and the phase separation performance generally improves as the density difference increases.

Although all of the candidate compositions met the bounding criterion for the $\mathrm{D}_{\mathrm{Cs}}$ values, only the current baseline composition meets the goal. Thus, a composition with $\mathrm{D}_{\mathrm{Cs}}$ values close to the goal is preferred because it would provide the ability to process waste blends that have properties that are modestly different from those of the waste simulant composition. The flow sheet robustness calculations suggest a BOBCalixC6 concentration between 6 and $8 \mathrm{~m} M$ and a modifier concentration between 0.65 and $0.85 \mathrm{M}$.

The combination of BOBCalixC6 solubility, $\mathrm{D}_{\mathrm{Cs}}$ values, and high flow sheet robustness, as well as the desire to have a low density, establishes the basis for the $7 \mathrm{~m} M$ BOBCalixC6 and $0.75 M$ Cs-7SB modifier concentration recommendation.

The $3 \mathrm{~m} M$ TOA concentration recommendation is based on three considerations. First, the flow sheet robustness calculations indicate that $10 \mathrm{~m} M$ TOA will require the use of an optimized solvent flow rate to achieve process performance above the bounding condition. Second, since TOA is the solvent component most susceptible to thermal and radiolytic decomposition, selecting a TOA concentration higher than the $1 \mathrm{~m} M$ baseline value will provide the CSSX process more resistance to the variations in anionic impurity content that are certain to be encountered with the different waste blends. Third, a TOA concentration greater than $1 \mathrm{~m} M$ will also provide greater flexibility in solvent preparation and process control.

The solvent dispersion numbers for all the solvent compositions tested against the waste simulant, scrub, and strip solutions met the selection criterion and consequently did not provide a means to differentiate between different solvent compositions. However, comparison of solvent dispersion numbers against the $0.01 \mathrm{M} \mathrm{NaOH}$ solvent wash solution indicates the need to reevaluate the $\mathrm{NaOH}$ concentration used for solvent washing. 
Although the viscosity, surface tension, and interfacial tension were not explicitly identified in any of the selection criteria, these physical properties can impact the dispersion number. Therefore, experimental determination of these properties was included in the study to verify that no unexpected behavior occurred. The experimental results did not reveal any such behavior.

\section{REFERENCES}

1. R. A. Dimenna et al., Bases, Assumptions, and Results of the Flow Sheet Calculations for the Decision Phase Salt Disposition Alternatives, WSRC-RP-99-00006, Rev. 3, Westinghouse Savannah River Company, Aiken, South Carolina, May 2001.

2. B. A. Moyer et al., Caustic-Side Solvent Extraction Chemical and Physical Properties: Progress in FY 2000 and FY 2001, CERS/SR/SX/019, Rev. 0, Oak Ridge National Laboratory, Oak Ridge, Tennessee, April 2001.

3. H. D. Harmon et al., Tanks Focus Area Savannah River Site Salt Processing Project Research and Development Program Plan, PNNL-13253, Rev. 1, Pacific Northwest National Laboratory, Richland, Washington, November 2000.

4. L. N. Klatt, Criteria for Optimum Composition of the Caustic-Side Solvent Extraction (CSSX) Solvent, CERS/SR/SX/025, Rev. 0, Oak Ridge National Laboratory, Oak Ridge, Tennessee, August 2001.

5. R. A. Peterson, Preparation of Simulated Waste Solutions for Solvent Extraction Testing, WSRC-RP-2000-00361, Rev. 0, Westinghouse Savannah River Company, Aiken, South Carolina, May 2000.

6. R. A. Leonard, "Solvent Characterization Using the Dispersion Number," Sep. Sci. 30(7-9), 1103-1122 (1995).

7. ASTM Standard D 891-95, "Standard Test Method for Specific Gravity, Apparent, of Liquid Industrial Chemicals," American Society for Testing and Materials, Philadelphia, 2000.

8. ASTM Standard D 1429-95, "Standard Test Methods for Specific Gravity of Water and Brine," American Society for Testing and Materials, Philadelphia, 2000.

9. ASTM Standard E 542-00, "Standard Practice for Calibration of Laboratory Volumetric Apparatus," American Society for Testing and Materials, Philadelphia, 2000.

10. ASTM Standard D 2196-99, "Standard Test Method for Rheological Properties of NonNewtonian Materials by Rotational (Brookfield Type) Viscometer," American Society for Testing and Materials, Philadelphia, 1999.

11. "The Brookfield Digital Viscometer Model DV-II Operating Instructions," Manual No. M/85-160-F, Brookfield Engineering Laboratories, Inc., Stoughton, Massachusetts, 1985. 
12. ASTM Standard D 971-99a, "Standard Test Method for Interfacial Tension of Oil Against Water by the Ring Method," American Society for Testing and Materials, Philadelphia, 1999.

13. ASTM Standard D 1331-89, "Standard Test Method for Surface and Interfacial Tension of Solutions of Surface-Active Agents," American Society for Testing and Materials, Philadelphia, 1989.

14. CRC Handbook of Chemistry and Physics, 66th ed., CRC Press, Boca Raton, Florida, 1985, p. F-32.

15. R. D. Spence, L. N. Klatt, L. H. Delmau, F. V. Sloop, Jr., P. V. Bonnesen, and B. A. Moyer, Batch-Equilibrium Hot-Cell Tests of Caustic-Side Solvent Extraction (CSSX) with SRS Simulant Waste and Internal ${ }^{137}$ Cs Irradiation, ORNL/TM-2001/49, Oak Ridge National Laboratory, Oak Ridge, Tennessee, September 2001.

16. R. A. Peterson, T. L. White, S. Crump, and L. H. Delmau, Solvent Extraction External Radiation Stability Testing, WSRC-TR-2000-00413, Rev. 0, Westinghouse Savannah River Company, Aiken, South Carolina, November 2000.

17. R. A. Leonard and M. C. Regalbuto, "A Spreadsheet Algorithm for Stagewise Solvent Extraction," Solvent Extr. Ion Exchange 12(5), 909-930 (1994).

18. J. F. Birdwell, Jr., and K. K. Anderson, Evaluation of 5-cm Centrifugal Contactor Hydraulic and Mass Transfer Performance for Caustic-Side Solvent Extraction of Cesium, ORNL/TM-2001/137, Oak Ridge National Laboratory, Oak Ridge, Tennessee, August 2001.

19. J. F. Birdwell, Jr., "Throughput Performance of a Fully-Pumping 5-cm Centrifugal Contactor with Vane Modifications," Tanks Focus Area (TFA) Plan of the Week (POW) Technical Discussion, Oak Ridge National Laboratory, Oak Ridge, Tennessee, November 5, 2001.

20. R. A. Leonard et al., Interim Report on a Multi-Day Test of the Caustic-Side Solvent Extraction Flow Sheet for Cesium Removal from a Simulated SRS Tank Waste, ANL-01/10, Argonne National Laboratory, Argonne, Illinois, April 2001.

21. S. G. Campbell et al., Demonstration of Caustic-Side Solvent Extraction with Savannah River Site High-Level Waste, WSRC-TR-2001-00223, Rev. 0, Westinghouse Savannah River Company, Aiken, South Carolina, April 2001.

22. L. H. Delmau et al., "Solvent Optimization," TFA POW Technical Discussion, Oak Ridge National Laboratory, Oak Ridge, Tennessee, October 29, 2001. 
Appendix A

PREDICTED $D_{\text {CS }}$ VALUES USING THE $\log$ VERSUS $\log$ RELATIONSHIPS BETWEEN $D_{\mathrm{Cs}}$ VALUES AND BOBCALIXC6 AND Cs-7SB MODIFIER CONCENTRATIONS 
Table A.1. Predicted $\mathrm{D}_{\mathrm{Cs}}$ values

\begin{tabular}{|c|c|c|c|}
\hline \multirow[b]{2}{*}{ Process step } & \multicolumn{3}{|c|}{ Cs-7SB modifier } \\
\hline & $0.70 M$ & $0.75 M$ & $0.80 M$ \\
\hline \multicolumn{4}{|c|}{ BOBCalixC6 $=6.5 \mathrm{~m} M$} \\
\hline Extraction & 12.76 & 13.08 & 13.40 \\
\hline Scrub no. 1 & 1.16 & 1.22 & 1.28 \\
\hline Scrub no. 2 & 1.21 & 1.26 & 1.31 \\
\hline Strip no. 1 & 0.91 & 0.096 & 0.101 \\
\hline Strip no. 2 & 0.054 & 0.057 & 0.059 \\
\hline Strip no. 3 & 0.043 & 0.045 & 0.047 \\
\hline Strip no. 4 & 0.037 & 0.039 & 0.041 \\
\hline \multicolumn{4}{|c|}{ BOBCalixC6 $=7.0 \mathrm{~m} M$} \\
\hline Extraction & 13.77 & 14.13 & 14.48 \\
\hline Scrub no. 1 & 1.26 & 1.32 & 1.38 \\
\hline Scrub no. 2 & 1.30 & 1.35 & 1.40 \\
\hline Strip no. 1 & 0.099 & 0.104 & 0.109 \\
\hline Strip no. 2 & 0.059 & 0.062 & 0.065 \\
\hline Strip no. 3 & 0.047 & 0.049 & 0.051 \\
\hline Strip no. 4 & 0.040 & 0.043 & 0.045 \\
\hline \multicolumn{4}{|c|}{ BOBCalixC6 = $7.5 \mathrm{~m} M$} \\
\hline Extraction & 14.78 & 15.18 & 15.56 \\
\hline Scrub no. 1 & 1.35 & 1.42 & 1.49 \\
\hline Scrub no. 2 & 1.39 & 1.45 & 1.50 \\
\hline Strip no. 1 & 0.106 & 0.112 & 0.117 \\
\hline Strip no. 2 & 0.060 & 0.070 & 0.070 \\
\hline Strip no. 3 & 0.051 & 0.053 & 0.055 \\
\hline Strip no. 4 & 0.044 & 0.046 & 0.048 \\
\hline
\end{tabular}


ORNL/TM-2001/258

\section{INTERNAL DISTRIBUTION}

\begin{tabular}{|c|c|}
\hline 1. J. F. Birdwell, Jr. & 10. T. G. Levitskaia \\
\hline 2. P. V. Bonnesen & 11. M. P. Maskarinec \\
\hline 3. L. H. Delmau & 12. B. A. Moyer \\
\hline 4. L. J. Foote & 13. Central Research Library \\
\hline 5-8. L. N. Klatt & 14. NSTD DMC-RC \\
\hline
\end{tabular}

\section{EXTERNAL DISTRIBUTION}

15. S. G. Campbell, Westinghouse Savannah River Company, P.O. Box 616, Building 704-3B, Aiken, SC 29808

16. J. T. Carter, Westinghouse Savannah River Company, P.O. Box 616, Building 704-3B, Aiken, SC 29808

17. N. F. Chapman, Westinghouse Savannah River Company, P.O. Box 616, Building 704-3B, Aiken, SC 29808

18. W. D. Clark, Jr., U.S. Department of Energy, Savannah River Operations Office, Bldg. 704-3N, Aiken, SC 29808

19. R. G. Edwards, Westinghouse Savannah River Company, P.O. Box 616, Building 704-3B, Aiken, SC 29808

20. S. D. Fink, Westinghouse Savannah River Company, P.O. Box 616, Building 773-A, Aiken, SC 29808

21. H. D. Harmon, Tanks Focus Area Salt Processing Program, P.O. Box 616, Building 704-3N, Aiken, SC 29808

22. R. T. Jones, Westinghouse Savannah River Company, P.O. Box 616, Building 704-3N, Aiken, SC 29808

23. R. A. Leonard, Argonne National Laboratory, Building 205, 9700 South Cass Avenue, Argonne, IL 60439

24. J. R. Noble-Dial, U.S. Department of Energy, Oak Ridge Operations Office, P.O. Box 2001, Oak Ridge, TN 37831

25. Michael Norato, Westinghouse Savannah River Company, P.O. Box 616, Building 773-A, Aiken, SC 29808 
26. Robert Pierce, Westinghouse Savannah River Company, P.O. Box 616, Building 773-A, Aiken, SC 29808

27. M. Regalbuto, Argonne National Laboratory, Building 205, 9700 South Cass Avenue, Argonne, IL 60439

28. P. C. Suggs, U.S. Department of Energy, Savannah River Operations Office, P.O. Box A, Building 704-3N, Aiken, SC 29808

29. W. L. Tamosaitis, Westinghouse Savannah River Company, P.O. Box 616, Building 773-A, Aiken, SC 29808

30. M. C. Thompson, Westinghouse Savannah River Company, P.O. Box 616, Building 773-A, Aiken, SC 29808

31. D. D. Walker, Westinghouse Savannah River Company, P.O. Box 616, Building 773-A, Aiken, SC 29808

32. W. R. Wilmarth, Westinghouse Savannah River Company, P.O. Box 616, Building 773-A, Aiken, SC 29808

33. Tanks Focus Area Technical Team, c/o B. J. Williams, Pacific Northwest National Laboratory, P.O. Box 999, MSIN K9-69, Richland, WA 99352

34. Tanks Focus Area Program Lead, c/o T. P. Pietrok, U.S. Department of Energy, Richland Operations Office, P.O. Box 550, MS: K8-50, Richland, WA 99352

35. Tanks Focus Area Headquarters Program Manager, c/o K. D. Gerdes, DOE Office of Science and Technology, 19901 Germantown Road, 1154 Cloverleaf Building, Germantown, MD 20874-1290 